\title{
Galectin-1 Cooperates with Yersinia Outer Protein (Yop) P to Thwart Protective Immunity by Repressing Nitric Oxide Production
}

\author{
Brenda Lucila Jofre ${ }^{1,2}$, Ricardo Javier Eliçabe ${ }^{1,2}$, Juan Eduardo Silva ${ }^{1,2}$, Juan Manuel Pérez Sáez ${ }^{3}$, \\ Maria Daniela Paez ${ }^{4}$, Eduardo Callegari ${ }^{4}$, Karina Valeria Mariño ${ }^{5}$, María Silvia Di Genaro ${ }^{1,2}$, \\ Gabriel Adrián Rabinovich ${ }^{3,6}$ and Roberto Carlos Davicino ${ }^{1,2,7}$,*
}

Citation: Jofre, B.L.; Eliçabe, R.J.; Silva, J.E.; Pérez Sáez, J.M.; Paez, M.D.; Callegari, E.; Mariño, K.V.; Di Genaro, M.S.; Rabinovich, G.A.; Davicino, R.C. Galectin-1 Cooperates with Yersinia Outer Protein (Yop) P to Thwart Protective Immunity by Repressing Nitric Oxide Production. Biomolecules 2021, 11, 1636. https:// doi.org/10.3390/biom11111636

Academic Editor: Alexander V. Timoshenko

Received: 1 September 2021

Accepted: 29 October 2021

Published: 4 November 2021

Publisher's Note: MDPI stays neutral with regard to jurisdictional claims in published maps and institutional affiliations.

Copyright: (c) 2021 by the authors. Licensee MDPI, Basel, Switzerland. This article is an open access article distributed under the terms and conditions of the Creative Commons Attribution (CC BY) license (https:// creativecommons.org/licenses/by/ $4.0 /)$.
1 División de Inmunología, Facultad de Química, Bioquímica y Farmacia, Universidad Nacional de San Luis, San Luis CP5700, Argentina; brendalucila.jofre@gmail.com (B.L.J.); javielicabe@gmail.com (R.J.E.); jesilva9@hotmail.com (J.E.S.); sdigena@gmail.com (M.S.D.G.)

2 Instituto Multidisciplinario de Investigaciones Biológicas (IMIBIO), Consejo Nacional de Investigaciones Científicas y Técnicas (CONICET), San Luis C5700, Argentina

3 Laboratorio de Glicomedicina, Instituto de Biología y Medicina Experimental (IBYME), Consejo Nacional de Investigaciones Científicas y Técnicas (IBYME-CONICET), Buenos Aires C1428ADN, Argentina; juanmanuelperezsaez@gmail.com (J.M.P.S.); gabyrabi@gmail.com (G.A.R.)

4 Division of Basic Biomedical Sciences, Sanford School of Medicine, University of South Dakota, Vermillion, SD 66544, USA; Daniela.Paez@usd.edu (M.D.P.); Eduardo.Callegari@usd.edu (E.C.)

5 Laboratorio de Glicómica Funcional y Molecular, Instituto de Biología y Medicina Experimental, Consejo Nacional de Investigaciones Científicas y Técnicas (IBYME-CONICET), Buenos Aires C1428ADN, Argentina; kmarino@ibyme.conicet.gov.ar

6 Departamento de Química Biológica, Facultad de Ciencias Exactas y Naturales, Universidad de Buenos Aires, Buenos Aires C1428, Argentina

7 Roberto Davicino, División de Inmunología, Facultad de Química, Bioquímica y Farmacia, Universidad Nacional de San Luis, Ejercito de los Andes 950, San Luis CP5700, Argentina

* Correspondence: rcdavici@unsl.edu.ar

Abstract: Yersinia enterocolitica (Ye) inserts outer proteins (Yops) into cytoplasm to infect host cells. However, in spite of considerable progress, the mechanisms implicated in this process, including the association of Yops with host proteins, remain unclear. Here, we evaluated the functional role of Galectin-1 (Gal1), an endogenous $\beta$-galactoside-binding protein, in modulating Yop interactions with host cells. Our results showed that Gal1 binds to Yops in a carbohydrate-dependent manner. Interestingly, Gal1 binding to Yops protects these virulence factors from trypsin digestion. Given that early control of Ye infection involves activation of macrophages, we evaluated the role of Gal1 and YopP in the modulation of macrophage function. Although Gal1 and YopP did not influence production of superoxide anion and/or TNF by Ye-infected macrophages, they coordinately inhibited nitric oxide (NO) production. Notably, recombinant Gal1 (rGal1) did not rescue NO increase observed in Lgals1 ${ }^{-/-}$macrophages infected with the YopP mutant Ye $\Delta y o p P$. Whereas NO induced apoptosis in macrophages, no significant differences in cell death were detected between Gal1deficient macrophages infected with Ye $\triangle y o p P$, and WT macrophages infected with Ye wt. Strikingly, increased NO production was found in WT macrophages treated with MAPK inhibitors and infected with Ye wt. Finally, rGal1 administration did not reverse the protective effect in Peyer Patches (PPs) of Lgals $^{-/-}$mice infected with Ye $\triangle y o p P$. Our study reveals a cooperative role of YopP and endogenous Gal1 during Ye infection.

Keywords: Yersinia enterocolitica; YopP; Galectin-1; nitric oxide; macrophages

\section{Introduction}

Yersinia enterocolitica (Ye), Yersinia pseudotuberculosis, and Yersinia pestis are the three human pathogenic bacteria in the genus Yersinia [1]. Ye causes food-borne self-limiting 
severe diarrhea, enteritis, and mesenteric lymphadenitis. In addition to gastrointestinal effects, Ye gradually spreads across the body, causing symptoms in the liver and spleen [2,3]. Ye uses a type III protein secretion machinery to deliver into host cells bacterial effector proteins encoded in the 70-kb Yersinia virulence plasmid (pYV). This plasmid includes a set of six effector Yersinia outer proteins (Yops): YopE, YopH, YopM, YopO/YpkA, YopP/YopJ, YopT [4]. YopH counteracts phagocytosis and T-cell activation [5,6], while YopE, YopT, and YopO disrupt actin cytoskeleton [7,8]. In addition, YopP/J inhibits nuclear factor kappa B (NF-kB) signaling, suppresses pro-inflammatory cytokines, modulates antigen uptake, and induces apoptosis in macrophages and dendritic cells [9-13]. Moreover, YopP inhibits the activation of MAPKs inactivating c-Jun-N-terminal kinase (JNK), p38, and extracellular signal-regulated 1/2 kinase (ERK1/2) [14-16]. In this context, YopP can interact directly or indirectly with specific kinases, acting as a "poison kinase" [16]. In this regard, YopP is an acetyltransferase, which uses acetyl-coenzymeA(acetyl-CoA) as a cofactor to acetylate critical serine and threonine residues in the activation loop of MAPKKs and IKK-I3 [12,17]. Surprisingly, MAPK as well as NF-kB, are constrained in scaffolds and the recruitment of YopP to such a scaffold would allow faster inhibition of signaling events compared to a free diffusion of YopP in the cell [18]. In addition, YopP is activated by the host cell factor inositolhexakisphosphate (IP6), which could also explain how YopP is kept in a quiescent state in the bacterium, since bacteria lack the capacity to synthesize IP6 [19]. In activated macrophages however, Yersiniae cause pyroptosis, a cell death program independent of YopP, which involves inflammasome activation and processing of caspase-1, release of pro-inflammatory cytokines IL-1 $\beta$ and IL-18, and eventually lysis of macrophages and release of pro-inflammatory intracellular content $[20,21]$. The prevention of pyroptosis and suppression of inflammatory response by YopP could be crucial for Yersiniae ability to colonize the Peyer's patches without an initial immune response [22-24]. In this context, the early control of Ye infection is mediated by innate immune mechanisms, involving natural killer (NK) cells, neutrophils and macrophages [25-27].

Interestingly, M1 and M2 macrophages refer to the two extremes of a spectrum of potential macrophage activation states; however the term M2 has been traditionally used for any macrophage activation states other than M1. The use of M2 as a generic term for macrophage activation is justified by the fact that they share a number of functional characteristics and are involved in immunoregulation and tissue remodeling. In this regard, threesubclassesof M2 macrophages have been identified: M2a, triggered by IL-4 or IL-13; M2b, induced by exposure to Toll-like receptor (TLR) agonists and IL-1R; and M2c, induced by IL-10 and glucocorticoids [28]. On the other hand, M1 macrophage activation is defined by high production of toxic intermediates, such as reactive oxygen species (ROS) and NO [28]. However, few reports are available on the role of NO in Ye infection [29,30]. We have previously shown increased NO synthesis and enhanced expression of inducible nitric oxide synthase (iNOS) in response to Ye antigens in macrophages from mice lacking the tumor necrosis factor receptor p55 (TNFRp55) [31]. These results suggested a role of TNFRp55 and NO in modulating macrophage functions after Ye infection. In addition, we have shown that Ye infection induces local and systemic up-regulation of Galectin-1 (Gal1), an endogenous immunomodulatory lectin, which blunts NO synthesis and limits bacterial clearance [32].

Through binding to $\beta$-galactoside-containing glycoconjugates, Gal1 triggers different biological processes including those operating during innate and adaptive immune responses, as well as those involving host-pathogen interactions. Gal1, as well as other members of this lectin family, can cross-link glycosylated receptors, including: the T cell receptor (TCR); pre-B cell receptor (pre-BCR) and CD45, facilitating their cell surface retention and modulating signaling thresholds [33,34]. In this regard, it has been demonstrated that glycan-binding proteins may serve as a bridge that regulates bacterial infection, internalization and immunity $[35,36]$.

Thus, given the emerging roles of Gal1 in infection [33,37-43] and based on our previous results showing that $Y$. enterocolitica induced a YopP dependent positive regulation 
of Gal1 [32], we hypothesized that Yops could interact with Gal1 and modulate the course of Ye infection. In the present work we studied the interactions between Yops and Gal1, focusing on the role of the Ye virulence factor YopP in shaping the course of early innate immune response upon Ye infection.

\section{Materials and Methods}

\subsection{Bacterial Culture and Purification of Yops}

Infection was performed with Ye serotype 0:8 (pYV+, WA-314) (Ye wt) or with Ye WA-314 deficient in YopP (pYV+, WA-C pYVNalrKanr) (Ye $\Delta y o p P$ ) [44], kindly provided by Ingo Autenrieth (Tuebingen, Germany). Bacteria were cultured as previously described [45], diluted 1:20, and incubated at $37^{\circ} \mathrm{C}$ with agitation for $2 \mathrm{~h}(180 \mathrm{rpm})$. The addition of EGTA (5 mM) for $\mathrm{Ca}^{2+}$ chelation, $\mathrm{MgCl}_{2}(15 \mathrm{mM})$, and glucose $(0.2 \%)$ induced Yops expression and secretion. Bacteria were grown at $37^{\circ} \mathrm{C}$ for 2 to $3 \mathrm{~h}$ and centrifuged $(10,000 \times g$ for $15 \mathrm{~min})$, and proteins were precipitated from culture supernatants with trichloroacetic acid (TCA) as previously described [46].

\subsection{Mice and Infection}

C57BL/ 6 Gal1 knockout (Lgals1 ${ }^{-/-}$) mice were kindly provided by F. Poirier (Institute Jacques Monod, Paris, France). C57BL/6 wild-type (WT) mice were purchased from the Animal Facilities of the National University of La Plata, La Plata, Argentina. Breeding colonies were established at the animal facilities of the National University of San Luis (San Luis, Argentina). Mice were housed in a cabinet (Ehret, Emmendingen, Germany) and given ad libitum sterile food and water. Male mice (6-8 wk-old) were used for all the experiments. The Animal Care and Use Committee of the National University of San Luis, Argentina, approved the experimental protocols (Protocol Number: B226/16).

Mice were starved for $2 \mathrm{~h}$ before being inoculated orogastrically with $5 \times 10^{8}$ bacteria in $0.2 \mathrm{~mL}$ sterile phosphate-buffered saline solution ( $\mathrm{pH} 7.4$ ) using a gastric tube. PBS was given to the control mice. Serial dilutions of the inoculated suspension were plated on Trypticase soy agar (Britania, Buenos Aires, Argentina) to monitor the real number of inoculated bacteria.

The PPs were removed in aseptic conditions and homogenized in PBS. Then, on MacConkey-Igarsan agar, duplicates of $50 \mu \mathrm{L}$ of serial dilutions of PPs homogenates were plated (Britania, Buenos Aires, Argentina). After $48-\mathrm{h}$ incubation period at $27^{\circ} \mathrm{C}$, colonyforming units (CFU) were counted. The limit of detectable CFU was $25\left(\log _{10} 25=1.4\right)$ [47].

\subsection{Stimulation of Peritoneal Macrophages}

Lgals1 ${ }^{-/-}$and WT resident peritoneal macrophages were isolated from mice of both genotypes using $10 \mathrm{mLof}$ sterile pyrogen-free saline solution, centrifuged twice at $200 \times g$ for $10 \mathrm{~min}$ at $4{ }^{\circ} \mathrm{C}$, and re-suspended in DMEM supplemented with $10 \%$ heat-inactivated fetal bovine serum (FBS) (Natocor, Córdoba, Argentina), 5 mM L-glutamine, $50 \mu \mathrm{M}$ 2-ME, $100 \mathrm{IU} / \mathrm{mL}$ penicillin, $100 \mu \mathrm{g} / \mathrm{mL}$ streptomycin, and $50 \mu \mathrm{g} / \mathrm{mL}$ gentamicin (Thermo Fisher Scientific, Waltham, Massachusetts, EEUU).This cellular suspension was seeded onto a 24-well culture plate (Costar, Tecnolab, Buenos Aires, Argentina) at $2 \times 10^{6}$ cells per well. After $24 \mathrm{~h}$ of incubation at $37^{\circ} \mathrm{C}$ in a $5 \% \mathrm{CO}_{2}$ atmosphere, adherent cells were washed three times with saline and incubated for $1 \mathrm{~h}$ at $37{ }^{\circ} \mathrm{C}$ in a $5 \% \mathrm{CO}_{2}$ atmosphere with or without Ye wt or Ye $\triangle y o p P$ (multiplicity of infection, moi: 10:1) in the absence or presence of $5 \mu \mathrm{M}$ ERK1/2 inhibitor (PD98059) or p38 inhibitor (SB203580) (Calbiochem, San Diego, CA, USA). To eliminate extracellular bacteria, $0.1 \mathrm{~g} / \mathrm{mL}$ of gentamicin was added. Cells were incubated overnight, and culture supernatants were collected [32].

\subsection{NO and Urea Determination}

The Griess reaction assay was used to measure nitrite synthesis in macrophage culture supernatants obtained $12 \mathrm{~h}$ after Ye infection [32]. In a 96-well flat-bottom plate, $100 \mu \mathrm{L}$ of culture supernatant was mixed with $100 \mu \mathrm{L}$ of Griess reagent and incubated for $10 \mathrm{~min}$ at 
room temperature. Absorbance at $550 \mathrm{~nm}$ was determined in a plate reader (Bio-Rad, New York, NY, USA). In addition, urea was measured in macrophage culture supernatants using the Urea Color 2R package (Wiener, Rosario, Argentina), according to the manufacturer's instructions.

\subsection{Apoptosis Assays}

Macrophages isolated from WT or Lgals1 ${ }^{-1-}$ mice were infected with Ye wt or with Ye $\triangle y o p P$ and incubated in a $5 \% \mathrm{CO}_{2}$ atmosphere. Dimethyl sulfoxide (DMSO) (Sigma, St. Louis, MO, USA) was used as a positive control for apoptosis. Cells $\left(1 \times 10^{6}\right)$ were suspended in binding buffer (10 mM HEPES pH 7.4, $140 \mathrm{mM} \mathrm{NaCl}, 2.5 \mathrm{mM} \mathrm{CaCl}_{2}$ ) after being washed twice with PBS. Macrophages were incubated for $15 \mathrm{~min}$ at room temperature in the dark with Annexin V-FITC (Sigma, St. Louis, MO, USA). The cells were washed and re-suspended in $500 \mu \mathrm{L}$ of binding buffer. Finally, macrophages were stained with propidium iodide (PI) (Sigma, St. Louis, MO, USA) and analyzed by flow cytometry using a FACSCalibur cytometer (Becton, Dickinson and Company, Franklin Lakes, NJ, USA).

\subsection{Preparation and Purification of $R G a l 1$}

Recombinant Gal1 (rGal1) was produced and purified as previously described [48]. Briefly, LGALS1 gene was cloned into a pET-3a (+) vector for bacterial expression between the NdeI and BamHI specific recognition sites. The plasmid was first amplified in DH5 $\alpha E$. coli and subsequently used for transformation of E. coli C41 (DE3) pLysS. The resulting protein was purified by affinity chromatography on a lactosyl-Sepharose resin. Purified Gal1 was dialyzed against PBS ( $\mathrm{pH}$ 6-9) for $6 \mathrm{~h}$, three times and then subjected to a Polymixin B affinity resin to remove endotoxins from protein solution. Protein was measured by the Pierce BCA Protein Assay Kit (Thermo Fisher, Carlsbad, CA, USA), according to the manufacturer protocol. The recombinant protein was sterilized by passage through a $0.22-\mu \mathrm{m}$ syringe filter, adjusted to $10 \mathrm{mg} / \mathrm{mL}$ in PBS and stored as frozen aliquots until used.

\subsection{ELISA Assays}

TNF and IL-10 were determined in supernatants of infected WT or Lgals1-/macrophages using capture ELISA kits (eBioscience, San Diego, CA, USA) according to the manufacturer's instructions. YopP was determined using a modified ELISA protocol described by Chatzipanagiotou et al., 2001 [49]. Briefly, Yops were prepared from Ye wt or Ye $\triangle$ yopP. ELISA plates (Corning, Kennebunk, ME, USA) were coated with Yops antigens $(10 \mu \mathrm{g} /$ well $)$ and the binding of rGal1 $(10 \mathrm{mg} / \mathrm{mL})$ was detected using rabbit anti-Gal1 antibodies $(1 / 1000)$. The absorbance was read at $450 \mathrm{~nm}$ using a plate reader (Bio-Rad, New York, NY, USA).

\subsection{Oxidative Burst Assay}

For this assay, we used a protocol described by Schopf et al. (1984) [50] and ROS products were evaluated by the reduction of nitro blue tetrazolium (NBT) (Sigma, St. Louis, MO, USA) to formazan. In all these assays, WT or $\mathrm{Lgals}^{-/-}$macrophages were infected with Ye wt or with Ye $\triangle y o p P$, then, $300 \mu \mathrm{L}$ of NBT was added and the reaction was stopped with $1 \mathrm{~N} \mathrm{HCl}$ (Tetrahedron, Buenos Aires, Argentina). Dioxane (Dorwill, Buenos Aires, Argentina) was used to obtain formazan, and the absorbance was determined in a microplate reader at $525 \mathrm{~nm}$ (Bio-Rad).

\subsection{In Vivo and In Vitro Supplementation of RGal1}

For in vivo phenotype-rescuing studies, four animal groups were used: groups 1 and 2 were $\mathrm{Lgals}^{-/-}$mice injected i.p. with rGal1 $(3.2 \mathrm{mg} / \mathrm{kg})$ or vehicle control daily for 5 days after Ye wt infection [32]; groups 3 and 4 were Lgals $^{-1-}$ mice injected i.p. with rGal1 $(3.2 \mathrm{mg} / \mathrm{kg})$ or vehicle control daily for 5 days after Ye $\Delta y o p P$ infection [32]. Mice were killed five days after infection, and CFU were counted in PPs homogenates as mentioned previously. 
For in vitro rescue experiments, peritoneal macrophages from $\operatorname{Lgals} 1^{-/-}$mice were pretreated with $4 \mu \mathrm{g} / \mathrm{mL}$ rGal1 for 2 has previously described [51], and then infected with Ye wt or Ye $\triangle y o p P$ as outlined above. Then, supernatants were obtained and tested for NO and urea production.

\subsection{Analysis of Yops-Gal1 Interactions by SDS-PAGE and Western Blot}

Briefly, $25 \mu \mathrm{L}$ of Yops were added to each well and resolved by $12 \%$ SDS-PAGE. Subsequently, bands were transferred onto a PVDF membrane (Bio-Rad, New York, NY, USA), which was then blocked with $3 \%$ bovine serum albumin (BSA) and incubated for $18 \mathrm{~h}$ at $4{ }^{\circ} \mathrm{C}$ in agitation with human rGal1 $(6 \mu \mathrm{g} / \mathrm{mL})$ or with rGall plus $30 \mathrm{mM}$ of lactose as a disaccharide competitor. Finally, an in-house generated polyclonal anti-Gal1 antibody [52] was diluted 1:1000 and the reaction was revealed using chemiluminescence detection kit (Amersham Biosciences, London, UK). To evaluate the importance of glycans in Yops-Gal1 interaction, glycan oxidation was achieved by treatment with $10 \mathrm{mM} \mathrm{NaIO}_{4}$ as previously described [53].

\subsection{Lectin Blotting}

Yops were run in $10 \%$ SDS-PAGE, and transferred onto $0.45-\mu \mathrm{m}$ PVDF membranes (BioRad). Membranes were then blocked with 3\% bovine serum albumin (BSA) and strips were probed with the biotinylated lectins listed in Table 1,as previously described [54]. Lectin binding was visualized using horseradish rabbit peroxidase (HRP)-conjugated streptavidin (Sigma) with and C-DiGit ${ }^{\circledR}$ Blot Scanner (LI-COR Biosciences, Lincoln, NE, USA).

Table 1. Lectins used for characterization of carbohydrate structures present in Yops.

\begin{tabular}{ccc}
\hline Lectin & Ligands Described & Reference \\
\hline & Gal $\beta(1-3)$ GalNAc & \\
Arachis Hypogaea & Gal $\beta(1-3)$ GlcNAc & \\
(Peanut agglutinin) (PNA) & Gal $\beta(1-4) G l c N A c$ & \\
& Lactose & \\
& Galactose & \\
Erythrina crystagalli (ECA) & Gal $\beta(1-4)$ GlcNAc \\
& Lactose $>$ GalNAc $>$ \\
\hline
\end{tabular}

\subsection{Yops Proteolysis Using Trypsin Digestion}

Yops obtained from Ye wt were incubated with or without rGal1 overnight. Samples were subsequently digested with trypsin $(200 \mu \mathrm{g} / \mathrm{mL}$ ) (Sigma) following the protocol described by Shevchenko et al. (2006) [57]. Digestion products were subjected to separation in denaturing SDS-PAGE and Yops-rGal1 association was evaluated by Western blot using anti-Gal1 antibodies (1:1000). The reaction was revealed by chemiluminescence using the C-DiGit ${ }^{\circledR}$ Blot Scanner (LI-COR Biosciences, EEUU).

\subsection{Schiff Staining}

Briefly, Yops were added to each well and resolved by SDS-PAGE, and subsequently the gel was immersed in $12.5 \%$ trichloroacetic acid overnight and then placed in $1 \%$ periodic acid. Finally, the gel was incubated with Schiff's reagent in the dark for $1 \mathrm{~h}$ and washed with $0.5 \%$ of sodium metabisulphite three times for $10 \mathrm{~min}$ followed by distilled water [58].

\subsection{Flow Cytometry}

Ye $\left(2 \times 10^{8} \mathrm{CFU}\right)$ were fixed in $3 \%$ paraformaldehyde for $2 \mathrm{~h}$ at room temperature, washed three times in phosphate-buffered saline (PBS), and stored at $-80^{\circ} \mathrm{C}$ in PBS containing $15 \%$ of glycerol. To determine galectin binding, $2 \times 10^{7}$ fixed bacteria were incubated with label free rGal1 as described [59] at a final concentration of $3.3 \mathrm{mM}(100 \mu \mathrm{g} / \mathrm{mL})$ for $1 \mathrm{~h}$ at $37^{\circ} \mathrm{C}$. After two washes with PBS/Tween $0.1 \%$, Gal1 binding was detected by 
incubation with a rabbit anti-human Gal1 antibody for $45 \mathrm{~min}$ at $4{ }^{\circ} \mathrm{C}$. Cells were then washed twice in $0.1 \%$ PBS-Tween, next, resuspended in $50 \mu \mathrm{L}$ of PBS with a polyclonal anti-rabbit FITC-conjugate antibody (1/200), and incubated for $30 \mathrm{~min}$ on ice. Galectin binding was determined using a flow cytometer (FACSCalibur), and at least $4 \times 10^{4}$ events were recorded. Gal1 binding was evaluated by calculating the Fluorescence Medium Index [\% positive gated bacteria multiplied by the geometric mean fluorescence] [60].

\subsection{Mass Spectrometry}

Proteins were separated through 1D-SDS-PAGE on $10 \%$ of polyacrylamide gels. Next, gels were stained with $0.1 \%$ of Coomassie R-250. Selected bands were excised from gels and sent to the Center for Chemical and Biological Studies by Mass Spectrometry (CEQUIBIEM), Faculty of Exact and Natural Sciences, University of Buenos Aires, where protein identification analysis was performed. Briefly, bands were de-stained with $50 \mathrm{mM}$ of ammonium bicarbonate/acetonitrile $(50 / 50 \% v / v)$, reduced with DTT, followed by alkylation with iodoacetamide. Trypsin sequencing grade was used for in-gel digestion (Promega, Madison, WI, USA). The tryptic digested peptides were resuspended in $0.1 \%$ formic acid in water, injected into Easy nLC 1000 (Thermo Scientific), and analyzed by tandem mass spectrometry using a QExactive Orbitrap mass spectrometer (Thermo Scientific) [61].

\subsection{Bioinformatics Analysis}

The Mascot Generic Format (mgf) files were extracted from a RAW files using Mascot Distiller program v2.6.2.0 (www.matrixscience.com, original search: 12 December 2019 and corroborated through a most recently search on 11 January 2021), and searched against Yop 20191212 in house customized database (accession WP_010891200.1 from RefSeq, NCBI, 1 sequence, 288 residues) using Mascot server 2.6.2 (www.matrixscience.com, similar date than Distiller) local license. MASCOT server v2.6.2 in MS/MS ion search mode was applied to conduct peptide matches (peptide masses and sequence tags) and protein searches using the database mentioned previously. The following parameters were established for search: carbamidomethyl (C) on cysteine was set as fixed, and variable modifications included asparagines and glutamine deamidation, and methionine oxidation, respectively. Only two missed cleavages were allowed. Monoisotopic masses were counted. The precursor peptide mass tolerance was set at $20 \mathrm{ppm}$. Fragment mass tolerance was $0.02 \mathrm{Da}$ and the ion score or expected cutoff was set at 5 . The MS/MS spectra were searched with MASCOT using a 95\% confidence interval $(\mathrm{CI} \%)$ threshold $(p<0.05)$, while minimum score of 14 was used for peptide identification. Furthermore, the error tolerance mode was set up at MASCOT search to corroborate potential peptides unidentified during the first search.

\subsection{Western Blot Analysis of INOS Expression}

WT or Lgals1 ${ }^{-/-}$macrophages were infected with Ye wt or Ye $\Delta y o p P$. Cell lysates $(40 \mu \mathrm{g}$ of protein/lane) were size fractionated in $12 \%$ SDS-polyacrylamide gel electrophoresis and transferred to a PVDF membrane. Membranes were incubated for $90 \mathrm{~min}$ in Tris buffered saline (TBS, pH 7.5)-3\% milk and then overnight with a 1:200 rabbit antibody against iNOS (Santa Cruz Biotechnology Inc., Santa Cruz, CA, USA). Membranes were washed with TBS$0.05 \%$ Tween 20 and incubated with a 1:1000 horseradish peroxidase-conjugated goat antirabbit IgG (Sigma, CA, USA). Immunodetection was performed using chemiluminescence, following the protocol provided by the manufacturer. The immunoreactive protein bands were analyzed using the ImageJ software.

\subsection{Statistical Analysis}

The Mann-Whitney U test or one-way ANOVA with the Dunnett multiple-comparison test were used to determine if the differences between the groups were significant. Results are expressed as the mean \pm SEM. All statistical analyses were carried out using Prism version 5.0 (GraphPad, La Jolla, CA, USA). $p$ values $<0.05$ were considered statistically significant. 


\section{Results}

\subsection{Galectin-1 Binds to YopP in Y. enterocolitica}

Previous findings demonstrated the presence of Yops in the membrane fraction of Ye [4]. To explore whether Gal1 can bind to Ye surface proteins, we performed flow cytometry and ELISA using Gal1 as a probe, either with Ye wt or Ye $\Delta y o p P$, a genetically modified bacteria devoid of YopP (Figure 1).

A
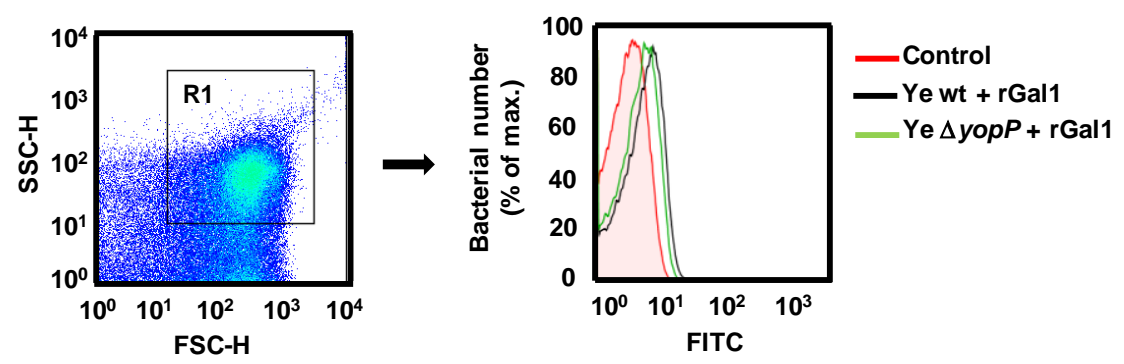

B

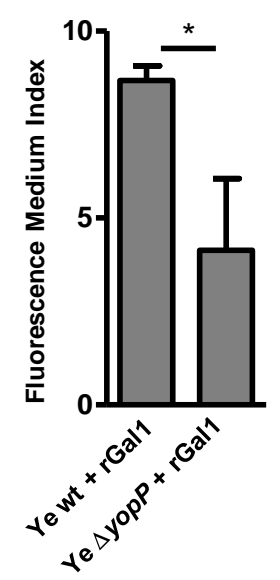

C

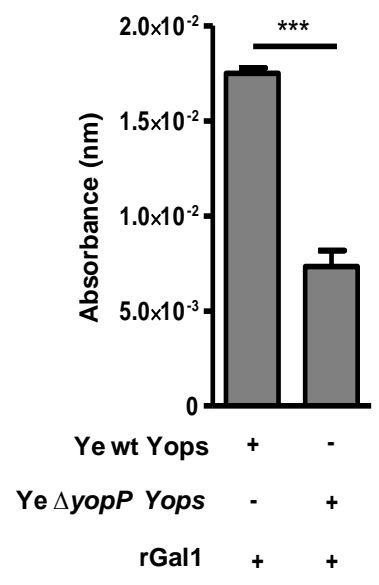

Figure 1. Galectin-1 Binds to Ye YopP.Binding of rGal1 to Ye wt (black) or to Ye $\triangle y o p P$ (green) is shown. Control (Ye without rGal1) is shown in red. Binding was analyzed by flow cytometry usinga FITC-conjugated anti-Gal1 antibody (A). Representative flow cytometry analysis of two independent experiments, showing the gate in Region 1 (R1) and the histogram expressing the number of FITCpositive bacteria. (B) Binding is expressed as the Fluorescence Medium Index. (C) ELISA plates were coated with Yops from Ye wt or Ye $\Delta y o p P(10 \mu \mathrm{g} /$ well) obtained under the same conditions and incubated with $10 \mathrm{mg} / \mathrm{mL}$ of rGal1. Gal1 binding was detected using an anti-Gal1 rabbit polyclonal antibody (1/1000). Data are the mean \pm SEM of three independent experiments $(\mathbf{B}, \mathbf{C}) .{ }^{*} p<0.05$, *** $p<0.001$.

We found a significant decrease in Gal1 binding to Ye $\Delta y o p P$ compared to Ye wt (Figure $1 \mathrm{~A}, \mathrm{~B} ; p<0.05$, Figure $1 \mathrm{C}, p<0.001$ ). Given that secretion of YopP by Ye is significantly lower than secretion of other Yops [62], these results suggest that YopP could mediate Gal1 binding to Ye, although other mediators maybe also contribute to this effect.

\subsection{Galectin-1 Recognizes Yops in a Carbohydrate-Dependent Manner}

To evaluate potential Gal1 ligands in Ye and given the glycan-binding activity of this protein, we studied whether Gal1-Ye interactions are mediated by specific glycans. 
Previous studies demonstrated that Ye spp. presents an alternative bacterial pathway, mediated by a cytoplasmic $\mathrm{N}$-glycosyltransferase, a homolog of Actinobacillus pleuropneumoniae HMW1C-Like glycosyltransferase (ApHMWC1LGT). This enzyme uses nucleotideactivated monosaccharides as donors to modify asparagine residues, and transfer glucose and galactose with $\mathrm{NX}(\mathrm{S} / \mathrm{T})$ as the acceptor sequon [63]. A secondary O-glycosylation activity was described for ApHMWC1LGT transferring a donor sugar to an acceptor sugar, forming di-hexoses on glycoproteins [64]. However, no data are available regarding the O-glycosylation pathway in this bacterium. We found, by means of a classical Schiff staining, that Yops are glycosylated (Figure 2A). In order to evaluate glycan-dependent binding of Gal1 to Yops, these glycoproteins were separated by SDS-PAGE and incubated with rGal1 in the absence or presence of lactose $(30 \mathrm{mM})$ as a competitive carbohydrate inhibitor of Gal1 binding activity (Figure 2A). Gal1-glycan interactions were inhibited by lactose at the level of protein bands corresponding to 14,25 and $35 \mathrm{kDa}$, suggesting carbohydrate-dependent binding of this lectin to secreted proteins of Ye. Thus, periodate treatment (which induces glycan oxidation) impaired Gal1 binding, indicating that Gal1-Yop interactions are mediated by specific glycosylated structures (Figure 2A).

A

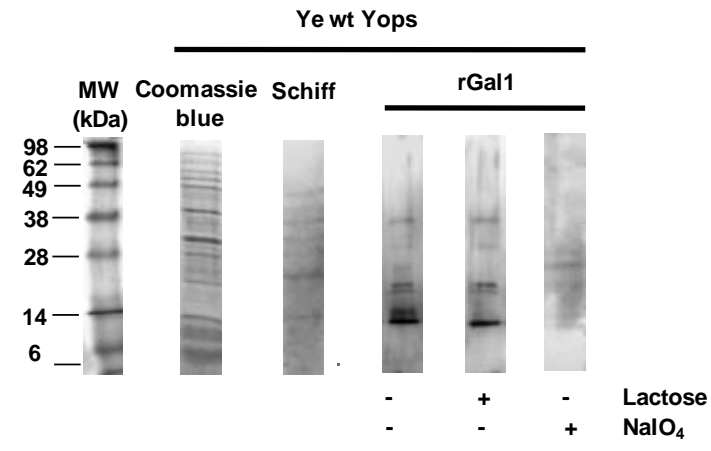

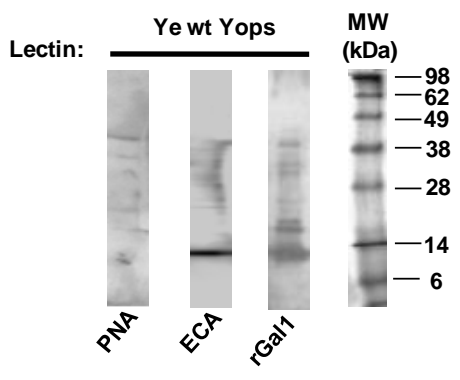

Figure 2. Virulence factors secreted by Y. enterocolitica are glycosylated and exhibit Gal1-permissive glycoepitopes. Electrophoresis was performed using an SDS-polyacrylamide gel $(25 \mu \mathrm{L}$ per well of Ye wt Yops; $20-40 \mu \mathrm{g} /$ well). Subsequently, gels were (A) treated with rGal1 $(6 \mu \mathrm{g} / \mathrm{mL})$, rGal1 and lactose $(30 \mathrm{mM})$ or $\mathrm{NaIO}_{4}(10 \mathrm{mM})$ or $(\mathbf{B})$ incubated with biotinylated Peanut agglutinin (PNA) or Erythrina cristagalli lectin (ECA), capable of recognizing disaccharides with lactose-derived structures. Detection was performed by Coomassie blue staining, Schiff staining (A) or revealed by chemiluminescence (B). Data are representative of two independent experiments.

Based on these findings, we next investigated the presence of Yops glyco-epitopes in electrophoretically-resolved protein bands, using biotinylated plant lectins able to recognize glycan structures permissive for Gal1 binding. Lectin blotting revealed the presence of 14-38 kDa bands that bound to Erythrina cristagalli (ECL), a lectin capable of recognizing non-sialylated $N$-acetyllactosamine (LacNAc, Gal $\beta(1-4)$ GlcNAc) structures. Notably, peanut agglutinin (PNA) reactivity was also (albeit faintly) observed, suggesting that Ye glycoproteins may also display glycans with Gal $\beta(1-3)$ terminal structures(Figure $2 \mathrm{~B}$ ). These results indicate that $\beta$-galactoside residues are exposed in Yops and may act as possible glycoepitopes for binding of host Gal1.

\subsection{Mass Spectrometry-Based Proteomics Analysis of Yops}

It has been demonstrated that YopP is a critical virulence factor involved in bacterial immune evasion [65] and Gal1 contributes to Ye-driven immunosuppression [32]. Separation of Yops proteins by 1D-SDS-PAGE and identification of bands using nanoLC-MS/MS analysis revealed selected bands corresponding to molecular weights ranging from 30 to $55 \mathrm{kDa}$ (Figure 3A, red square) with nineteen identified peptides matching YopP, including the $\mathrm{N}$ - and $\mathrm{C}$-terminus, and representing a $60 \%$ of sequence coverage of the protein (Figure 3B and Table 2). 


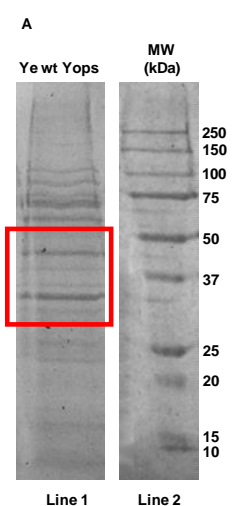

BP_010891200.1 Sequence of Type III secretion system, YopJ family, effector protein YopP [Y. enterocolitica]

MIGPISQINSFGGLSEKETRSLISNEELKNIIIQLETDIADGSWFHKNYS RLDIEVMPALVIQANNKYPEMNLNFVTSPQDLSIEIKNVIENGVGSSRFIINMGEGGIHFSVIDYKHI MIGPISQINSFGGLSEKETRSLISNEELKNIIIILETDIADGSWFHKNYSRLDIEVMPALVIQANNKYPEMNLNFVTSPQDLSIEIKNVIENGVGSSRFIINMGEGGIHFSVIDYKHI
NGKTSLLFEPVNFNSMGPAILAISTKTAIERYQLPDCHFSMVEMDIQRSSSECGIFSLALAKKLYTERDSLLKIHEDNIKGILSDSENPLPHNLDPYLPVTFYKHTQGKKRLNE YLNTNPQGVGTVVNKKNETIFNRFDNNKSIIDGKELSVSVHKKRIAEYKTLLKV

Amino acids in red indicate the sequence coverage $(60 \%)$,

Line $1 \quad$ Line 2

Figure 3. Protein bands derived from Yops selected for MS/MS analysis.Yops were solved in 1D- SDS-PAGE gels and stained with Coomassie Blue G-250 (A, Lane 1). Molecular weight markers (MW) are shown in (A), Lane 2. The red squares indicate bands subjected to identification through MS/MS analysis. YopP peptides identified (highlighted in red) in the selected bands and protein coverage map of Type III secretion system YopJ family effectors are shown in (B).

Table 2. YopP peptides identified through nLC-MS/MS analysis.

\begin{tabular}{|c|c|c|c|c|c|c|c|c|}
\hline Observed $^{a}$ & Mass Expt ${ }^{b}$ & Mass (Theor) ${ }^{c}$ & $\begin{array}{l}\text { Delta Error } \\
\text { (Da) }^{d}\end{array}$ & Pep_exp_z ${ }^{e}$ & Start $^{\mathrm{f}}$ & End $\mathrm{g}$ & Peptide Sequence ${ }^{\text {h }}$ & Modifications ${ }^{i}$ \\
\hline 707.816 & 2120.4261 & 2120.0208 & 0.4053 & +3 & 232 & 250 & $\begin{array}{l}\text { LNEYLNTNPQG } \\
\text { VGTVVNKK }\end{array}$ & $\begin{array}{l}\text { Deamidated (NQ); } \\
\text { Lys->CamCys (K) }\end{array}$ \\
\hline 1123.8687 & 3368.5843 & 3367.5 & 1.0843 & +3 & 100 & 122 & $\begin{array}{l}\text { FIINMGEGGIHF } \\
\text { SVIDYKHINGK }\end{array}$ & $\begin{array}{c}\text { Deamidated (NQ); } \\
\text { Lys->CamCys (K); } \\
\text { Hex(1)HexNAc(1) } \\
(\mathrm{N}) ; \\
\operatorname{Hex}(1) \operatorname{HexNAc}(1) \\
\text { (ST); Oxidation (M) }\end{array}$ \\
\hline 1344.4664 & 2686.9182 & 2686.2353 & 0.6829 & +2 & 48 & 67 & $\begin{array}{l}\text { NYSRLDIEVM } \\
\text { PALVIQANNK }\end{array}$ & $\begin{array}{c}\text { Deamidated (NQ); } \\
\text { Hex(1)HexNAc(1) } \\
(\mathrm{N}) \text {; Lys->CamCys } \\
(\mathrm{K})\end{array}$ \\
\hline 954.9102 & 2861.7088 & 2861.3441 & 0.3647 & +3 & 258 & 276 & $\begin{array}{l}\text { FDNNKSIIDG } \\
\text { KELSVSVHK }\end{array}$ & $\begin{array}{c}\text { Deamidated (NQ); } 2 \\
\operatorname{Hex}(1) \operatorname{HexNAc}(1) \\
\text { (ST) }\end{array}$ \\
\hline 470.2974 & 938.5802 & 937.5219 & 1.0583 & +2 & 284 & 288 & TLLKV & $\begin{array}{c}\operatorname{Hex}(1) \operatorname{HexNAc}(1) \\
(\mathrm{ST})\end{array}$ \\
\hline 604.0027 & 1205.9908 & 1205.5122 & 0.4787 & +2 & 182 & 187 & KLYTER & $\begin{array}{c}\operatorname{Hex}(1) \operatorname{HexNAc}(1) \\
(\mathrm{ST}) ; \text { Lys->CamCys } \\
(\mathrm{K})\end{array}$ \\
\hline 559.2594 & 1674.7563 & 1673.6991 & 1.0572 & +3 & 250 & 262 & KNETIFNR FDNNK & $\begin{array}{l}\text { Deamidated (NQ); } \\
\text { Lys->CamCys (K) }\end{array}$ \\
\hline 599.2961 & 1794.8664 & 1793.7499 & 1.1165 & +3 & 21 & 29 & SLISNEELK & $\begin{array}{c}\operatorname{Hex}(1) \operatorname{HexNAc}(1) \\
(\mathrm{N}) ; \\
\operatorname{Hex}(1) \operatorname{HexNAc}(1) \\
(\mathrm{ST}) ; \operatorname{Lys}->\operatorname{CamCys} \\
(\mathrm{K})\end{array}$ \\
\hline 761.4185 & 1520.8224 & 1520.7471 & 0.0754 & +2 & 200 & 213 & GILSDSEN PLPHNK & Deamidated (NQ) \\
\hline 515.7982 & 1544.3728 & 1544.6201 & -0.2473 & +3 & 251 & 262 & NETIFNR FDNNK & $\begin{array}{l}\text { Deamidated (NQ); } \\
\text { Lys->CamCys (K) }\end{array}$ \\
\hline 1092.9822 & 3275.9248 & 3275.4749 & 0.4499 & +3 & 1 & 20 & $\begin{array}{l}\text { MIGPISQINSF } \\
\text { GGLSEKETR }\end{array}$ & $\begin{array}{c}\text { Deamidated (NQ); } \\
\operatorname{Hex}(1) \operatorname{HexNAc}(1) \\
(\mathrm{N}) ; 2 \\
\text { Hex(1)HexNAc(1) } \\
\text { (ST); Oxidation (M) }\end{array}$ \\
\hline 525.9216 & 1574.7429 & 1574.7069 & 0.036 & +3 & 263 & 276 & SIIDGKEL SVSVHK & Lys->CamCys (K) \\
\hline 525.2371 & 2621.1492 & 2620.2921 & 0.8571 & +5 & 30 & 51 & $\begin{array}{l}\text { NIIIQLETDIAD } \\
\text { GSWFHKNYSR }\end{array}$ & Deamidated (NQ) \\
\hline 890.7302 & 3558.8918 & 3558.7498 & 0.142 & +4 & 1 & 29 & $\begin{array}{l}\text { MIGPISQINSF } \\
\text { GGLSEKETRS } \\
\text { LISNEELK }\end{array}$ & $\begin{array}{l}\text { Deamidated (NQ); } \\
\operatorname{Hex}(1) \operatorname{HexNAc}(1) \\
(\mathrm{N}) \text {; Oxidation (M) }\end{array}$ \\
\hline 532.2823 & 1062.55 & 1062.5193 & 0.0307 & +2 & 225 & 230 & HTQGKK & $\begin{array}{c}\operatorname{Hex}(1) \underset{H e x N A c}{\operatorname{Hex}(1)} \\
\text { (ST) }\end{array}$ \\
\hline 533.9495 & 1598.8266 & 1598.8767 & -0.05 & +1 & 278 & 288 & RIAEYKTLLK & $\begin{array}{c}\operatorname{Hex}(1) \operatorname{HexNAc}(1) \\
\text { (ST) }\end{array}$ \\
\hline
\end{tabular}


Table 2. Cont.

\begin{tabular}{|c|c|c|c|c|c|c|c|c|}
\hline Observed $^{\text {a }}$ & Mass Expt ${ }^{b}$ & Mass (Theor) ${ }^{c}$ & $\begin{array}{l}\text { Delta Error } \\
\text { (Da) }{ }^{d}\end{array}$ & Pep_exp_z ${ }^{e}$ & Start $^{\mathrm{f}}$ & End $\mathrm{g}$ & Peptide Sequence ${ }^{\text {h }}$ & Modifications $^{\mathrm{i}}$ \\
\hline 793.7171 & 2378.1295 & 2378.0999 & 0.0296 & +2 & 2 & 17 & IGPISQINS FGGLSEK & $\begin{array}{c}\text { Deamidated (NQ); } 2 \\
\text { Hex(1)HexNAc(1) } \\
\text { (ST) }\end{array}$ \\
\hline 642.8429 & 1283.6713 & 1282.4918 & 1.1795 & +3 & 225 & 230 & HTQGKKR & $\begin{array}{c}\text { Hex }(1) H e x N A c(1) \\
\text { (ST); } 2 \text { Lys->CamCys } \\
(\mathrm{K})\end{array}$ \\
\hline 793.4021 & 2377.1845 & 2376.9625 & 0.2219 & +3 & 258 & 268 & FDNNK SIIDGK & $\begin{array}{c}\operatorname{Hex}(1) \operatorname{HexNAc}(1) \\
(\mathrm{N}) ; \\
\operatorname{Hex}(1) \operatorname{HexNAc}(1) \\
\text { (ST); Lys->CamCys } \\
\text { (K) }\end{array}$ \\
\hline
\end{tabular}

a The $m / z$ (mass to charge state ratio) observed at the mass spectrometer, ${ }^{\mathrm{b}}$ The experimental mass of the peptide measured at the mass spectrometer, ${ }^{c}$ The theoretical mass of the peptide obtained from the data base after in silico digestion, $d$ The error of the peptide mass in Da calculated from theoretical mass minus experimental mass obtained from the mass spectrometry analysis, ${ }^{\text {e }}$ Peptide charge state after nanoESI ionization, ${ }^{\mathrm{f}}$ Position of the first residue of the peptide identified in the whole protein sequence, $\mathrm{g}$ Position of the last residue of the peptide identified in the whole protein sequence, ${ }^{h}$ Peptide sequence retrieved from the protein database after the bioinformatics analysis, ${ }^{i}$ Potential modifications observed at the peptide identified.

\subsection{Gal1 Protects Yops from Protease Degradation}

It has been well established that certain members of the galectin family, such as galectin-4 (Gal4), protect the brush border enzymes in the small intestine of the action of proteinases and lipases through binding to these enzymes [66]. To investigate whether Ye can take advantage of Gal1-glycan interactions and protect Yops from degradation, Yops were incubated with rGal1 and then treated with trypsin $(200 \mu \mathrm{g} / \mathrm{mL})$, separated by SDS-PAGE, and incubated with polyclonal anti-Gal1 antibodies. The results demonstrate the binding of Gal1 to two particular protein bands running in 14 and $35 \mathrm{kDa}$ (Figure 4), suggesting that this lectin might protect these glycoproteins from protease digestion. Since purified Yops could also contain other proteins. Future studies should be conducted to analyze their identity.

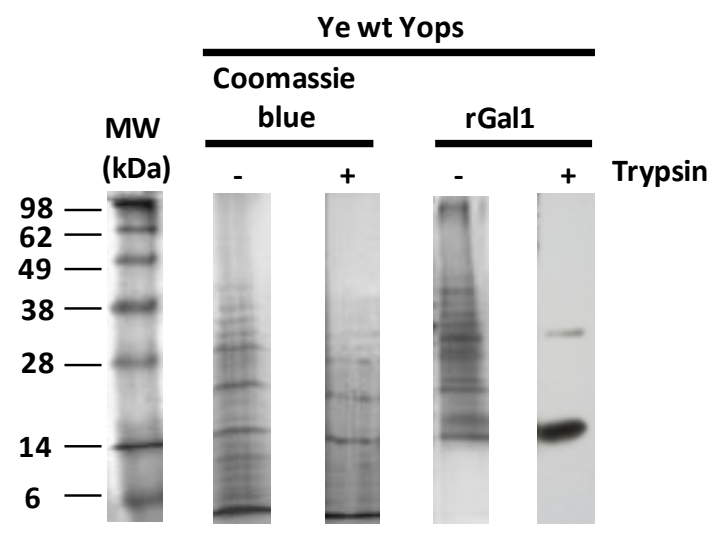

Figure 4. Gal1 protects virulence factors secreted by Ye from protease degradation. Electrophoresis was performed in an SDS-polyacrylamide gel ( $25 \mu \mathrm{L}$ per well of Ye wt Yops; $20-40 \mu \mathrm{g} /$ well). Subsequently, gels were treated with trypsin $(200 \mu \mathrm{g} / \mathrm{mL})$. Detection was performed by Coomassie blue staining or revealed by chemiluminescence. Data are representative of two independent experiments.

\subsection{Gal1 and YopP Control Y. enterocolitica Infection by Decreasing NO Production}

To further address the functional relevance of Gal1-YopP interactions during Ye infection, we first evaluated the impact this endogenous lectin in oxidative burst and inflammatory response. Given that superoxide $\left(\mathrm{O}_{2}{ }^{-}\right)$and tumor necrosis factor (TNF) contribute to innate responses of resident macrophages [67], we evaluated the $\mathrm{O}_{2}{ }^{-}$and TNF production by Ye-infected resident macrophages in the presence or absence of Gal1. We found that $\mathrm{O}_{2}{ }^{-}$ and TNF were not significantly different in $\mathrm{Lgals}^{-/-}$macrophages infected with Ye wt or Ye $\triangle$ yop $P$ compared with macrophages isolated from WT infected mice (Figure 5A,B). Inter- 
estingly, in spite of the ability of YopP to inhibit TNF through MAPKs [14], we found no significant difference in TNF production by Ye $\triangle y o p P$-infected WT macrophages compared to WT macrophages infected with Ye wt (Figure 5A). In this sense, the production of IL-10 was evaluated, given its well-established role in attenuating TNF synthesis [30]. We studied IL-10 production byn WT and Lgals1 ${ }^{-1-}$ macrophages infected with Ye wt or Ye $\Delta y o p P$, and found no significant changes in its synthesis (Figure 5C) Then, we analyzed NO production by WT or Lgals1 ${ }^{-/}$peritoneal macrophages after in vitro Ye infection.Remarkably, Gal1 and YopP induced a substantial regulation of NO and urea production (Figure 5D,E; $p<0.05)$. However, no significant differences in apoptosis were detected between WT and Lgals $1^{-1}$ macrophages infected in vitro with Ye $\triangle y o p P$ or Ye wt (Figure 5F).
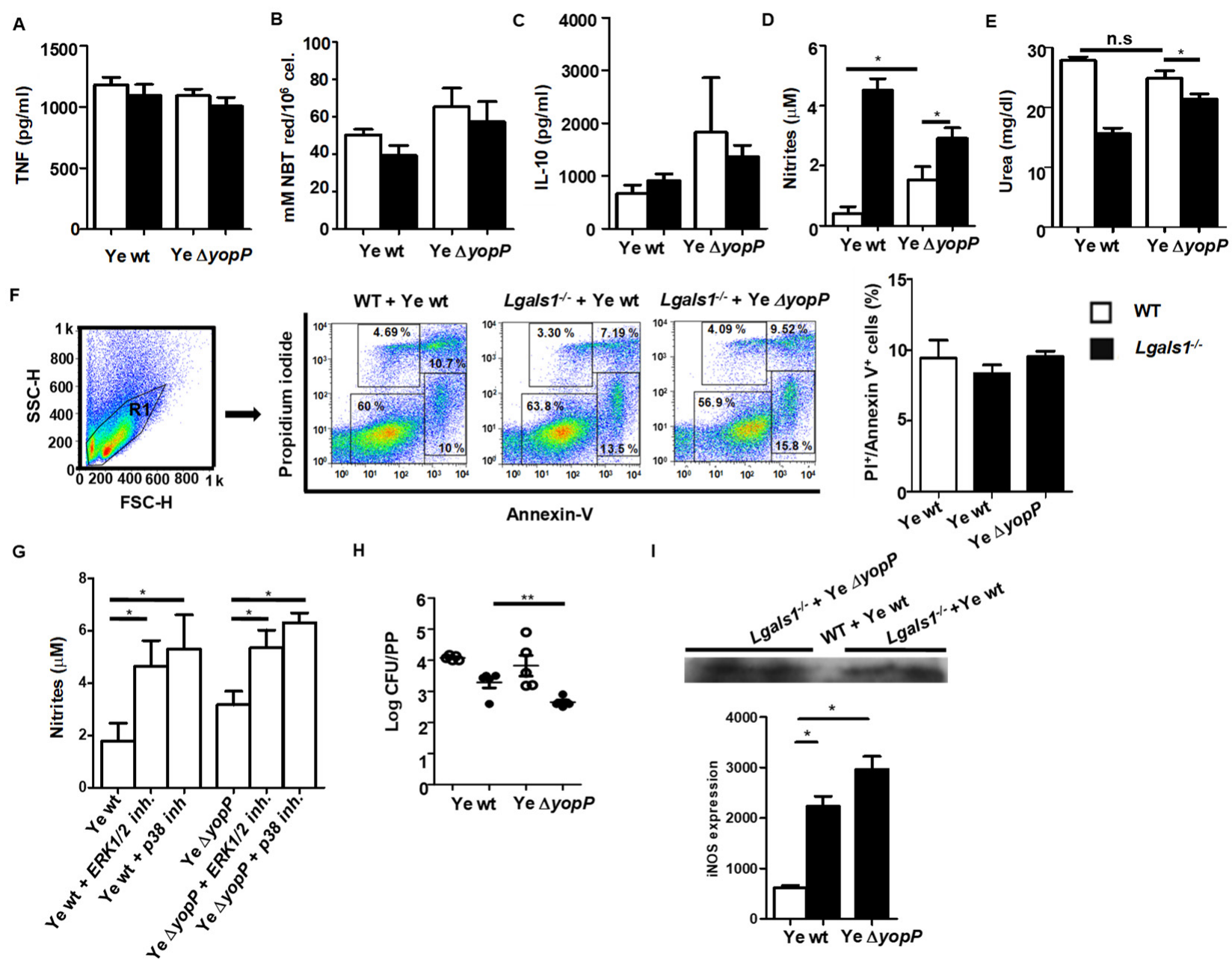

H

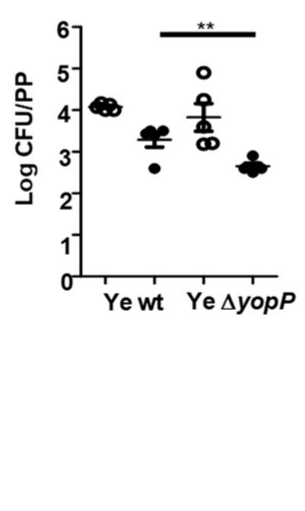

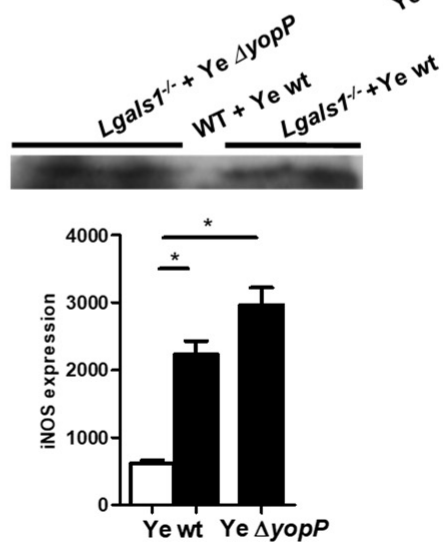

Figure 5. Lack of Gal1 and YopP induces NO Production and Confers Protection Against Ye. WT and Lgals1 ${ }^{-/-}$macrophages were infected with Ye wt or Ye $\triangle y o p P$ for $1 \mathrm{~h}$. TNF and IL-10 were determined in culture supernatants by ELISA (A,C). Superoxide anion was determined as described in Materials and methods (B). NO production was measured in WT and Lgals1 ${ }^{-/-}$macrophages after Ye Wt or Ye $\triangle y o p P$ infection for $1 \mathrm{~h}$ (D). Urea was determined in culture supernatant as an indirect assessment of arginase activity (E). Macrophages were isolated from Lgals1 ${ }^{-/}$or WT mice, infected in vitro with Ye wt or Ye $\triangle y o p P$ for $2 \mathrm{~h}$, stained with annexin- $\mathrm{V}$ and propidium iodide and analyzed by flow cytometry. In the gated Region 1 (R1), the percentage of annexin $-\mathrm{V}^{+}$propidium iodide ${ }^{+}$cells are shown (right panel) (F). NO production in macrophages infected in vitro with Ye wt or Ye $\triangle y o p P$ in the absence or presence of ERK1/2 or p38 inhibitors (G). CFU were evaluated in PPs of mice infected with Ye wt or with Ye $\triangle y o p P$ after 5 days. Limit of detectable CFU was $25\left(\log _{10} 25=1.4\right)(\mathbf{H})$. After infection, macrophage lysates were analyzed by Western blot using specific antibodies against iNOS (I). Data are the mean \pm SEM of three independent experiments (A-F right panel and I bottom panel), representative of three independent experiments (F left panel and I upper panel) or representative of two independent experiments (H, $n=5$ mice per group). ${ }^{*} p<0.05,{ }^{* *} p<0.01$. 
To investigate possible mechanisms underlying this immunomodulatory effect, we inhibited ERK1/2 or p38 signaling pathways and then infected macrophages with Ye wt or Ye $\Delta y о p P$.Ye-driven suppression of NO synthesis was significantly prevented when both signaling pathways were interrupted (Figure 5G, $p<0.05$ ). To evaluate whether the lack of Gal1 and/or YopP influences the clearance of Ye, we assessed bacterial load in PPs of WT or Lgals1 ${ }^{-/-}$mice after 5 days of infection with Ye wt or with Ye $\Delta y o p P$. Significantly lower numbers of CFU were detected in PPs of Ye $\triangle y o p P$ infected Lgals1 $1^{-/}$mice (Figure $5 \mathrm{H}$, $p<0.01)$.

To confirm the effect of Ye $\Delta y o p P$ infection and Gal1 on NO, iNOS expression was evaluated by Western blot. We observed inhibition of iNOS expression when WT macrophages were infected with Ye wt. On the contrary, an increased expression of iNOS was detected when Lgals1 ${ }^{-/-}$macrophages were infected with Ye wt and Ye $\Delta y o p P$ (Figure 5I, $p<0.05$ ).

3.6. Exogenous Supplementation of rGal1 Does Not Influence the Protective Anti-Y. enterocolitica Response Observed in the Absence of YopP

To evaluate the role of Gal1 and YopP in hindering anti-Y. enterocolitica immunity, we explored whether exogenous rGal1 could override the protective effect observed in Lgals $1^{-/-}$hosts infected with Ye $\triangle y o p P$. In this regard, we have previously demonstrated that administration of exogenous rGal1 in Ye wt-infected ggals1 $^{-/-}$mice abolished protection compared with untreated control Lgals1 $1^{-/-}$mice [32]. However, the administration of rGal1 to Lgals1 $1^{-/-}$mice infected with Ye $\triangle y o p P$ showed a similar CFU number in PPs (Figure 6A), and no significant differences were observed in both $\mathrm{NO}$ and urea production when compared with the control group (Figure 6B,C), suggesting that the exogenous lectin does not restore the phenotype generated by Gal1 and/or YopP deficiency.

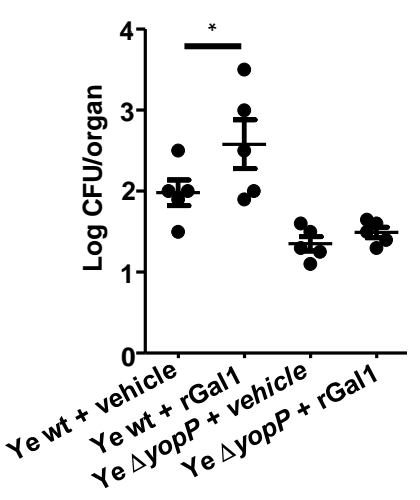

B

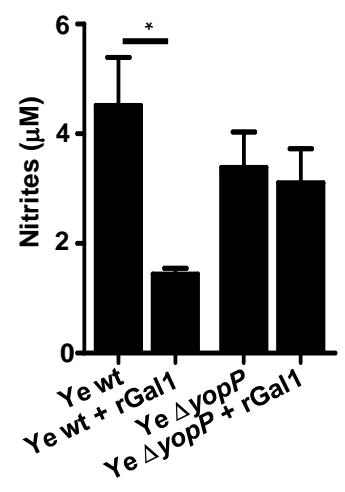

C

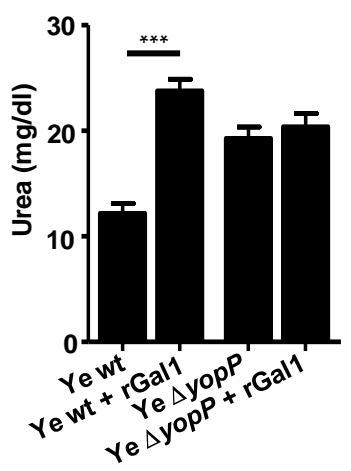

Figure 6. Exogenous Supplementation of rGal1 does not Revert the Protective Anti-Ye Response Observed in the Absence of YopP. Lgals1 ${ }^{-/-}$mice were treated i.p. with rGal1 or vehicle control daily for $5 \mathrm{~d}$, starting on the day of infection. Mice were euthanized at day 5 , and CFU were determined in homogenates of PPs. Limit of detectable CFU was $25\left(\log _{10} 25=1.4\right)(\mathrm{A}) . \mathrm{Lgals}^{-/}$macrophages were infected with Ye wt or Ye $\Delta y o p P$ for $1 \mathrm{~h}$ in the presence or absence of rGal1. NO production was determined in supernatants using Griess assay (B). Urea was determined in culture supernatants as an indirect evaluation of arginase activity $(\mathbf{C})$. Data are representative of two independent experiments ( $n=5$ mice per group) (A). Data are mean \pm SEM of two independent experiments $(\mathbf{B}, \mathbf{C}) .{ }^{*} p<0.05$, *** $p<0.001$.

\section{Discussion}

Ye are Gram-negative bacteria that invade the intestine and use the type III protein secretion machinery to deliver bacterial effector proteins to host cells [2,4]. Similar to other microbes, the mechanisms underlying infection and immune evasion processes may involve bacterial glycoproteins recognized by host lectins, [36,43]. Several innate and adaptive immune cells, including macrophages, dendritic cells (DCs), and activated B and T cells, are an important source of Gal1 secretion [52,68-70]. In turn, this endogenous 
lectin controls the magnitude and nature of immune responses through diverse mechanisms including modulation of M1-M2 macrophage polarization, DC immunogenicity, regulatory $\mathrm{T}$ (Treg) cell expansion, $\mathrm{T}$ helper cell differentiation, and apoptosis [51,70-76]. Interestingly, Gal1 and its glycosylated ligands could be potentially used by pathogens as a glyco-checkpoint to subvert innate and adaptive immune programs [77]. In this sense, bacterial proteins such as Chlamydial membrane proteins MOMP and OmcB showed a permissive glycosylation pattern for Gal1 binding [43], and Gal-1 expressed by human cervical epithelial cells binds to the virulence factor lipophosphoglycan of Trichomonas vaginalis in a carbohydrate-dependent manner [78]. Additionally, Nita-Lazar et al. showed that upon influenza infection, Streptococcus pneumoniae adhesion to the airway epithelial surface is enhanced via the coordinated action of host galectins and viral and pneumococcal neuraminidases [79]. In this study, we provide evidence that Yops-secreted proteins from Ye- may bind Gal1 through carbohydrate-dependent mechanisms. Even though data on Ye glycosylation are still scarce, our findings showed the presence of permissive glycoepitopes for Gal1 binding in Yops, and particularly the relevant role of YopP in Gal1 binding to Ye, as demonstrated in binding experiments with Ye $\triangle y o p P$. Although alternative proteins, other than Yops, could be secreted from Ye [80], optimal culture conditions are offered for Yops secretion, among them, the addition of EGTA $(5 \mathrm{mM})$ for $\mathrm{Ca}^{2+}$ chelation, $\mathrm{MgCl}_{2}(15 \mathrm{mM})$, and glucose $(0.2 \%)$ [46]. Under these conditions, Yops represent a major component of the Ye secretome [81]. In this sense, a mass spectrometry-based identification of YopP showed several potentially glycosylated peptides; however, the poor number of $b$ and $y$ ion series during fragmentation, as well as low signal-to-noise ratio, hampered their full characterization. Further structural studies using a pre-enrichment technique and other strategies to improve the detection and analysis of glycopeptides would be relevant for a more complete understanding of Ye glycosylation pathways. Additionally, immunoprecipitation would also be useful to specifically verify these interactions.

Interestingly, we previously demonstrated that YopP up-regulates Gal1 expression in mouse splenocytes [32]. Here we found that Gal1 binds to the Ye surface and that lack of the critical effector protein YopP disrupts this association, highlighting specific interactions between YopP and Gal1. Although the functional role of Gal1-YopP interactions is unknown, previous studies showed a scaffold role for this lectin in other cell systems [82,83]. In this sense, we found that Gal1 prevents trypsin degradation of Yops. This finding is consistent with previous results demonstrating the biological relevance of this lectin in resistance to trypsin [84] and elastase [65] digestion. In this regard, using the software PeptideCutter (ExPASy), we identified several cleavage sites for trypsin on YopP and other Yops sequence (data not shown). Thus, Gal1 binding to Yops could represent an evolutionarily conserved mechanism to render bacterial virulence factors resistant to proteases implicated in infection.

It has been well established that macrophages confer early protection during the course of Ye infection [85]. NO synthesized by inducible iNOS is a major effector pathway of inflammatory macrophages; this inflammatory mediator plays essential roles in anti-microbial responses and host defense. Arginase catalyzes the alternative arginine metabolic pathway, which converts arginine to ornithine and urea [86]. Gal1 regulates L-arginine metabolism in peritoneal macrophages and microglia in this fashion by shifting the balance from classically-activated M1-type toward alternatively-activated M2-type macrophages and microglia [51,76].On the other hand, previous studies suggested that Yops corresponding to pathogenic Yersinia spp. inhibit LPS-mediated production of NO by macrophages [30]. Likewise, in the present study we found that YopP inhibited NO production and increased urea levels in a coordinate fashion with Gal1. In agreement with our findings, Silva Monnazzi et al. and Tansini et al. demonstrated that NO production in murine macrophages is suppressed by Y. pseudotuberculosis and that the YopP counterpart, YopJ, could be, at least in part, responsible of such effect $[87,88]$. In addition, we observed increased NO production by WT macrophages after inhibition of p38 and ERK1/2 signaling pathways and subsequent infection with Ye wt or Ye $\Delta y o p P$. These results are in 
agreement with our previous results showing that Gal1 production is regulated, at least in part, through p38 and ERK1/2 signaling pathways [32]. Although high levels of nitrogen species can damage basic cellular components and trigger cell death in macrophages [89], no significant differences in apoptosis were detected in $\operatorname{Lgals}^{-/-}$peritoneal macrophages infected with Ye $\triangle y o p P$ compared with the WT counterparts. In this regard, NO is a multifaceted molecule with dichotomous regulatory functions. Whereas it promotes apoptosis in several cell types, it prevents execution of cell death programs in other settings through specific inhibition of caspases [90].

Interestingly, Boland et al. (1998) showed that YopP inhibits TNF release by infected macrophages. Moreover, Giordano et al. (2011) [91] reported increased expression of pro-inflammatory cytokines, including TNF, in iNOS deficient innate immune cells. These results indicate that $\mathrm{NO}$ can inhibit the production of pro-inflammatory cytokines, which are usually produced by M1 macrophages [92] These data are in agreement with the unaltered TNF levels in absence of YopP, which could be due to the increased amounts of NO production.

A remarkable feature of macrophages is their plasticity. The classically-activated proinflammatory M1-type macrophages constitute one end of the spectrum, while alternatively activated anti-inflammatory M2 macrophages are on the other. Pro-inflammatory cytokines and mediators such as TNF and ROS are synthesized by M1 macrophages while anti-inflammatory factors such as IL-10, TGF- $\beta$, and arginase are considerably expressed in M2 macrophages [93]. To determine if a pro- or anti-inflammatory condition prevails in the presence of Gal1, we evaluate iNOS expression and IL-10 production in macrophages. We observed a key role of Gall in the negative modulation of iNOS expression, this finding is in agreement with those obtained by Starossom et al. (2012) who demonstrated that expression of iNOS mRNA was significantly decreased by Gal1 in M1 mice microglia [76]. In future studies, it would be useful to evaluated the polarization and inflammatory state of macrophages by monitoring their gene expression profile. On the other hand, it is wellknown that IL-10 inhibits macrophage function and controls inflammation [92]. Moreover, several results showed that apoptotic macrophages trigger production of IL-10 [20,22]. We demonstrated that rGal1 supplementation restored NF-kB activation. TNF synthesis, and IL-6 production in PPs from Lgals-1 ${ }^{-/}$mice to levels comparable to those attained in WT hosts [32]. Here, we observed that administration of exogenous rGal1 to Lgals $^{-1}{ }^{-/-}$ macrophages infected with Ye $\triangle y o p P$ was not sufficient to restore decreased NO production and increased urea levels. Moreover, we observed that administration of exogenous Gal1 did not thwart the antibacterial protective effect unleashed in the absence of endogenous Gal1 and YopP. These results suggest that Gal1 and the bacterial virulence factor, YopP, might be crucial to regulate Ye pathogenesis using a coordinated mechanism, as has been reported for YopJ and IKK $\beta$, MKK1, MKK2, MKK3, MKK4, MKK5, MKK6 $[16,94]$ and IP6 [19]. Thus, in response to Ye infection, Gal1 and the virulence factor YopP may limit anti-bacterial responses. Conversely, deficiency in YopP or Gal1 controls the clearance of Ye and increases NO production. Additionally, our results suggest that ERK1/2 and p38 pathways mediate inhibition of NO production driven by Ye through mechanisms that could potentially involve regulation of Gal1 expression [95].

Thus, host derived Gal1 and glycosylated ligands may contribute to Ye infection by associating with YopP. In this regard, our studies identify glycosylation-dependent interactions between endogenous Gal1 and Yops that may play an important role during Ye infection through modulation of NO production. These findings may have critical implications in the design of tailored therapies aimed at controlling anti-bacterial responses during Ye infection. However, in spite of considerable progress, the clinical implications of our findings as well as the molecular mechanisms underlying YopP-Gal-1 interactions remain to be further investigated.

Author Contributions: Conceptualization, G.A.R., M.S.D.G. and R.C.D.; methodology, J.M.P.S. and K.V.M.; validation, B.L.J. and R.C.D.; formal analysis, B.L.J., R.J.E., J.E.S., M.D.P., E.C., K.V.M., M.S.D.G. and R.C.D.; investigation, B.L.J., R.J.E., M.S.D.G. and R.C.D.; resources, J.M.P.S., M.D.P., 
E.C., G.A.R., K.V.M. and M.S.D.G.; writing—original draft preparation, K.V.M., M.S.D.G. and R.C.D.; writing-review and editing, B.L.J., R.J.E., J.E.S., M.D.P., E.C., G.A.R., K.V.M., M.S.D.G. and R.C.D.; visualization, B.L.J., R.J.E., J.E.S., E.C., G.A.R., M.S.D.G. and R.C.D.; supervision, G.A.R. and M.S.D.G.; funding acquisition, G.A.R., M.S.D.G. and R.C.D. All authors have read and agreed to the published version of the manuscript.

Funding: This research was funded by grants from Consejo Nacional de Investigaciones Científicas y Técnicas (CONICET; PIP 00815), Universidad Nacional de San Luis, PROICO 2-1218, Fundación Sales and Fundación Bunge y Born.

Institutional Review Board Statement: The study was conducted according to the guidelines of the Declaration of Helsinki and approved by the The Animal Care and Use Committee of the National University of San Luis, Argentina (Protocol Number: B226/16).

Informed Consent Statement: Not applicable.

Acknowledgments: We are grateful to Ingo Autenrieth for providing Ye wt and Ye yopP strains. We also thank Gabinete de Asesoramiento en Escritura Científica en Inglés (GAECI) staff for writing assistance and Messrs. Ryan Johnson and Bill Conn from USD-IT Research Computing for their help in server operation and maintenance.

Conflicts of Interest: The authors declare no conflict of interest.

\section{References}

1. Wren, B.W. The Yersiniae-A model Genus to Study the Rapid Evolution of Bacterial Pathogens. Nat. Rev. Microbiol. 2003, 1, 55-64. [CrossRef] [PubMed]

2. Autenrieth, I.B.; Firsching, R. Penetration of M Cells and Destruction of Peyer's Patches by Yersinia Enterocolitica: An ultrastructural and Histological Study. J. Med. Microbiol. 1996, 44, 285-294. [CrossRef] [PubMed]

3. Bottone, E.J. Yersinia Enterocolitica: Overview and Epidemiologic Correlates. Microbes Infect. 1999, 1, 323-333. [CrossRef]

4. Cornelis, G.R.; Boland, A.; Boyd, A.P.; Geuijen, C.; Iriarte, M.; Neyt, C.; Sory, M.-P.; Stainier, I. The Virulence Plasmid of Yersinia, an Antihost Genome. Microbiol. Mol. Biol. Rev. 1998, 62, 1315-1352. [CrossRef] [PubMed]

5. Alonso, A.; Bottini, N.; Bruckner, S.; Rahmouni, S.; Williams, S.; Schoenberger, S.P.; Mustelin, T. Lck Dephosphorylation AT Tyr-394 and Inhibition of T Cell Antigen Receptor Signaling by Yersinia phosphatase yopH. J. Biol. Chem. 2004, 279, 4922-4928. [CrossRef] [PubMed]

6. Grosdent, N.; Maridonneau-Parini, I.; Sory, M.P.; Cornelis, G.R. Role of Yops and adhesins in resistance of Yersinia enterocolitica to phagocytosis. Infect. Immunity 2002, 70, 4165-4176. [CrossRef]

7. Viboud, G.I.; Bliska, J.B. Yersinia outer Proteins: Role in Modulation of Host Cell Signaling Responses and Pathogenesis. Annu. Rev. Microbiol. 2005, 59, 69-89. [CrossRef] [PubMed]

8. Grabowski, B.; Schmidt, M.A.; Rüter, C. Immunomodulatory Yersinia Outer Proteins (Yops)-Useful Tools for Bacteria and Humans Alike. Virulence 2017, 8, 1124-1147. [CrossRef]

9. Ruckdeschel, K.; Mannel, O.; Richter, K.; Jacobi, C.A.; Trülzsch, K.; Rouot, B.; Heesemann, J. Yersinia Outer Protein P of Yersinia Enterocolitica Simultaneously Blocks the nuclear factor- $\mathrm{kb}$ pathway and exploits lipopolysaccharide Signaling to Trigger Apoptosis in Macrophages. J. Immunol. 2001, 166, 1823-1831. [CrossRef] [PubMed]

10. Erfurth, S.E.; Gröbner, S.; Kramer, U.; Gunst, D.S.; Soldanova, I.; Schaller, M.; Autenrieth, I.B.; Borgmann, S. Yersinia enterocolitica Induces Apoptosis and Inhibits Surface Molecule Expression and Cytokine Production in Murine Dendritic Cells. Infect. Immun. 2004, 72, 7045-7054. [CrossRef] [PubMed]

11. Thiefes, A.; Wolf, A.; Doerrie, A.; Grassl, G.A.; Matsumoto, K.; Autenrieth, I.; Bohn, E.; Sakurai, H.; Niedenthal, R.; Resch, K.; et al. The Yersinia Enterocolitica Effector YopP Inhibits Host Cell Signalling by Inactivating the Protein Kinase TAK1 in the IL-1 Signalling Pathway. EMBO Rep. 2006, 7, 838-844. [CrossRef]

12. Mittal, R.; Peak-Chew, S.-Y.; McMahon, H.T. Acetylation of MEK2 and I B kinase (IKK)Activation Loop Residues by YopJ Inhibits Signaling. Proc. Natl. Acad. Sci. USA 2006, 103, 18574-18579. [CrossRef]

13. Autenrieth, S.E.; Soldanova, I.; Rösemann, R.; Gunst, D.; Zahir, N.; Kracht, M.; Ruckdeschel, K.; Wagner, H.; Borgmann, S.; Autenrieth, I.B. Yersinia Enterocolitica Yopp Inhibits Map Kinase-Mediated Antigen Uptake in Dendritic Cells. Cell. Microbiol. 2007, 9, 425-437. [CrossRef]

14. Boland, A.; Cornelis, G.R. Role of Yopp in Suppression of Tumor Necrosis Factor Alpha Release by Macrophages during Yersinia Infection. Infect. Immun. 1998, 66, 1878-1884. [CrossRef] [PubMed]

15. Ruckdeschel, K.; Harb, S.; Roggenkamp, A.; Hornef, M.; Zumbihl, R.; Köhler, S.; Heesemann, J.; Rouot, B. Yersinia Enterocolitica Impairs Activation of Transcription Factor Nf-Kb: Involvement in the Induction of Programmed Cell Death and in the Suppression of the Macrophage Tumor Necrosis Factor $\alpha$ Production. J. Exp. Med. 1998, 187, 1069-1079. [CrossRef] [PubMed]

16. Orth, K. Inhibition of the Mitogen-Activated Protein Kinase Kinase Superfamily by a Yersinia Effector. Science 1999, 285, 1920-1923. [CrossRef] 
17. Ma, K.W.; Ma, W. YopJ Family Effectors Promote Bacterial Infection through a Unique Acetyltransferase Activity. Microbiol. Mol. Biol. Rev. 2016, 80, 1011-1027. [CrossRef] [PubMed]

18. Shaw, A.S.; Filbert, E.L. Scaffold proteins and immune-cell signaling. Nat. Rev. Immunol. 2009, 9, 47-56. [CrossRef] [PubMed]

19. Mittal, R.; Peak-Chew, S.Y.; Sade, R.S.; Vallis, Y.; McMahon, H.T. The Acetyltransferase Activity of the Bacterial Toxin YopJ of Yersinia Is Activated by Eukaryotic Host Cell Inositol Hexakisphosphate. J. Biol. Chem. 2010, 285, 19927-19934. [CrossRef]

20. Fink, S.L.; Cookson, B.T. Apoptosis, Pyroptosis, and Necrosis: Mechanistic Description of Dead and Dying Eukaryotic Cells. Infect. Hnmun. 2005, 73, 1907-1916. [CrossRef]

21. Bergsbaken, T.; Cookson, B.T. Innate immune response during Yersinia infection: Critical modulation of cell death mechanisms through phagocyte activation. Leukoc. Biol. 2009, 86, 1153-1158. [CrossRef] [PubMed]

22. Philip, N.H.; Brodsky, I.E. Cell death programs in Yersinia immunity and pathogenesis. Front. Cell. Infect. Microbiol. 2012, 2, 149. [CrossRef]

23. Monack, D.M.; Mecsas, J.; Bouley, D.; Falkow, S. Yersinia-induced apoptosis in vivo aids in the establishment of a systemic infection of mice. J. Expr. Med. 1998, 188, 2127-2137. [CrossRef] [PubMed]

24. Bergsbaken, T.; Cookson, B.T. Macrophage Activation Redirects Yersinia-Infected Host Cell Death from Apoptosis to Caspase-1Dependent Pyroptosis. PLoS Pathog. 2007, 3, e161. [CrossRef]

25. Hanski, C.; Naumann, M.; Grützkau, A.; Pluschke, G.; Friedrich, B.; Hahn, H.; Riecken, E.O. Humoral and Cellular Defense against Intestinal Murine Infection with Yersinia Enterocolitica. Infect. Immun. 1991, 59, 1106-1111. [CrossRef]

26. Autenrieth, I.B.; Hantschmann, P.; Heymer, B.; Heesemann, J. Immunohistological Characterization of the Cellular Immune Response against Yersinia Enterocolitica in Mice: Evidence for the Involvement of t Lymphocytes. Immunobiology 1993, 187, 1-16. [CrossRef]

27. Olson, R.M.; Dhariwala, M.O.; Mitchell, W.J.; Anderson, D.M. Yersinia Pestis Exploits Early Activation of myd88 for Growth in the Lungs during Pneumonic Plague. Infect. Immun. 2019, 87. [CrossRef] [PubMed]

28. Mantovani, A.; Sica, A.; Sozzani, S.; Allavena, P.; Vecchi, A.; Locati, M. The Chemokine System in Diverse Forms of Macrophage Activation and Polarization. Trends Immunol. 2004, 25, 677-686. [CrossRef] [PubMed]

29. Tufano, M.A.; Rossano, F.; Catalanotti, P.; Liguori, G.; Marinelli, A.; Baroni, A.; Marinelli, P. Properties of Yersinia Enterocolitica Porins: Interference with Biological Functions of Phagocytes, Nitric Oxide Production and Selective Cytokine Release. Res. Microbiol. 1994, 145, 297-307. [CrossRef]

30. Carlos, I.Z.; Silva Monnazzi, L.G.; Falcão, D.P.; de Medeiros, B.M.M. TNF- $\alpha, \mathrm{H}_{2} \mathrm{O}_{2}$ and No Response of Peritoneal Macrophages to Yersinia Enterocolitica O:3 Derivatives. Microbes Infect. 2004, 6, 207-212. [CrossRef] [PubMed]

31. Eliçabe, R.J.; Arias, J.L.; Rabinovich, G.A.; Di Genaro, M.S. TNFRp55 Modulates Il-6 and Nitric oxide Responses Following Yersinia Lipopolysaccharide Stimulation in Peritoneal Macrophages. Immunobiology 2011, 216, 1322-1330. [CrossRef]

32. Davicino, R.C.; Méndez-Huergo, S.P.; Eliçabe, R.J.; Stupirski, J.C.; Autenrieth, I.; Di Genaro, M.S.; Rabinovich, G.A. Galectin-1Driven Tolerogenic Programs Aggravate Yersinia enterocolitica infection by Repressing antibacterial immunity. J. Immunol. 2017, 199, 1382-1392. [CrossRef]

33. Baum, L.G.; Garner, O.B.; Schaefer, K.; Lee, B. Microbe-Host Interactions Are Positively and Negatively Regulated BY GalectinGlycan Interactions. Front. Immunol. 2014, 5. [CrossRef] [PubMed]

34. Cerliani, J.P.; Blidner, A.G.; Toscano, M.A.; Croci, D.O.; Rabinovich, G.A. Translating the 'Sugar Code' into Immune and Vascular Signaling Programs. Trends Biochem. Sci. 2017, 42, 255-273. [CrossRef] [PubMed]

35. Raman, R.; Tharakaraman, K.; Sasisekharan, V.; Sasisekharan, R. Glycan-Protein Interactions in viral pathogenesis. Curr. Opin. Struct. Biol. 2016, 40, 153-162. [CrossRef]

36. Davicino, R.C.; Eliçabe, R.J.; Di Genaro, M.S.; Rabinovich, G.A. Coupling Pathogen Recognition to Innate Immunity through Glycan-Dependent Mechanisms. Int. Immunopharmacol. 2011, 11, 1457-1463. [CrossRef]

37. Rabinovich, G.A.; Gruppi, A. Galectins as immunoregulators during infectious Processes: From Microbial Invasion to the Resolution of the Disease. Parasite Immunol. 2005, 27, 103-114. [CrossRef]

38. Vasta, G.R. Roles of Galectins in Infection. Nat. Rev. Microbiol. 2009, 7, 424-438. [CrossRef] [PubMed]

39. Liu, F.-T.; Rabinovich, G.A. Galectins: Regulators of Acute and Chronic Inflammation. Ann. N. Y. Acad. Sci. 2010, 1183, 158-182. [CrossRef]

40. Salatino, M.; Rabinovich, G.A. Fine-Tuning Antitumor Responses through the Control of Galectin-Glycan Interactions: An Overview. Methods Mol. Biol. 2010, 355-374. [CrossRef]

41. Chen, H.-Y.; Weng, I.-C.; Hong, M.-H.; Liu, F.-T. Galectins as Bacterial Sensors in the HOST Innate Response. Curr. Opin. Microbiol. 2014, 17, 75-81. [CrossRef] [PubMed]

42. Méndez-Huergo, S.P.; Blidner, A.G.; Rabinovich, G.A. Galectins: Emerging Regulatory Checkpoints Linking tumor Immunity and angiogenesis. Curr. Opin. Immunol. 2017, 45, 8-15. [CrossRef] [PubMed]

43. Lujan, A.L.; Croci, D.O.; Tudela, J.A.G.; Losinno, A.D.; Cagnoni, A.J.; Mariño, K.V.; Damiani, M.T.; Rabinovich, G.A. GlycosylationDependent Galectin-Receptor Interactions Promotechlamydia Trachomatisinfection. Proc. Natl. Acad. Sci. USA $2018,115$. [CrossRef] [PubMed]

44. Adkins, I.; Köberle, M.; Gröbner, S.; Bohn, E.; Autenrieth, I.B.; Borgmann, S. Yersinia Outer Proteins E, H, P, and T Differentially Target the Cytoskeleton and Inhibit Phagocytic Capacity of Dendritic Cells. Int. J. Med. Microbiol. 2007, 297, 235-244. [CrossRef] [PubMed] 
45. Eliçabe, R.J.; Cargnelutti, E.; Serer, M.I.; Stege, P.W.; Valdez, S.R.; Toscano, M.A.; Rabinovich, G.A.; Di Genaro, M.S. Lack of Tnfr P55 Results in Heightened Expression of Ifn- $\gamma$ and IL-17 during the Development of Reactive Arthritis. J. Immunol. 2010, 185, 4485-4495. [CrossRef] [PubMed]

46. Trülzsch, K.; Sporleder, T.; Igwe, E.I.; Rüssmann, H.; Heesemann, J. Contribution of the Major Secreted Yops of Yersinia enterocolitica O:8 to Pathogenicity in the mouse Infection Model. Infect. Immun. 2004, 72, 5227-5234. [CrossRef] [PubMed]

47. Autenrieth, I.B.; Beer, M.; Bohn, E.; Kaufmann, S.H.; Heesemann, J. Immune Responses to Yersinia enterocolitica in Susceptible BALB/c and Resistant C57BL/6 Mice: An Essential Role for gamma interferon. Infect. Immun. 1994, 62, 2590-2599. [CrossRef] [PubMed]

48. Sáez, J.M.P.; Hockl, P.F.; Cagnoni, A.J.; Huergo, S.P.M.; García, P.A.; Gatto, S.G.; Cerliani, J.P.; Croci, D.O.; Rabinovich, G.A. Characterization of a neutralizing anti-human galectin-1 monoclonal antibody with angioregulatory and immunomodulatory activities. Angiogenesis 2021, 24, 1-5. [CrossRef] [PubMed]

49. Chatzipanagiotou, S.; Legakis, J.N.; Boufidou, F.; Petroyianni, V.; Nicolaou, C. Prevalence of Yersinia Plasmid-Encoded Outer protein (Yop) Class-Specific Antibodies in Patients with Hashimoto's Thyroiditis. Clin. Microbiol. Infect. 2001, 7, 138-143. [CrossRef]

50. Schopf, R.E.; Mattar, J.; Meyenburg, W.; Scheiner, O.; Hammann, K.P.; Lemmel, E.-M. Measurement of the Respiratory Burst in Human Monocytes and Polymorphonuclear Leukocytes by Nitro Blue Tetrazolium Reduction and Chemiluminescence. J. Immunol. Methods 1984, 67, 109-117. [CrossRef]

51. Correa, S.G. Opposite Effects of Galectin-1 on Alternative Metabolic Pathways of 1-Arginine in Resident, Inflammatory, and Activated Macrophages. Glycobiology 2002, 13, 119-128. [CrossRef] [PubMed]

52. Rabinovich, G.A.; Iglesias, M.M.; Modesti, N.M.; Castagna, L.F.; Wolfenstein-Todel, C.; Riera, C.M.; Sotomayor, C.E. Activated rat macrophages produce a galectin-1-like protein that induces apoptosis of T cells: Biochemical and functional characterization. $J$. Immunol. 1998, 160, 4831-4840.

53. Reinhold, B.B.; Hauer, C.R.; Plummer, T.H.; Reinhold, V.N. Detailed Structural Analysis of a novel, Specific O-Linked glycan from the prokaryote Flavobacterium Meningosepticum. J. Biol. Chem. 1995, 270, 13197-13203. [CrossRef]

54. Croci, D.O.; Cerliani, J.P.; Dalotto-Moreno, T.; Méndez-Huergo, S.P.; Mascanfroni, I.D.; Dergan-Dylon, S.; Toscano, M.A.; Caramelo, J.J.; García-Vallejo, J.J.; Ouyang, J.; et al. Glycosylation-Dependent Lectin-Receptor Interactions preserve Angiogenesis IN Anti-VEGF Refractory Tumors. Cell 2014, 156, 744-758. [CrossRef] [PubMed]

55. Sharma, V.; Srinivas, V.R.; Adhikari, P.; Vijayan, M.; Surolia, A. Molecular Basis of Recognition by Gal/Galnac Specific Legume Lectins: Influence of Glu 129 on the Specificity of Peanut agglutinin (pna) towards c2-substituents of Galactose. Glycobiology 1998, 8, 1007-1012. [CrossRef] [PubMed]

56. Debray, H.; Montreuil, J.; Lis, H.; Sharon, N. Affinity of Four Immobilized Erythrina lectins toward Various N-linked Glycopeptides and Related Oligosaccharides. Carbohydr. Res. 1986, 151, 359-370. [CrossRef]

57. Shevchenko, A.; Tomas, H.; Havli, J.; Olsen, J.V.; Mann, M. In-Gel Digestion for Mass Spectrometric Characterization of Proteins and Proteomes. Nat. Protoc. 2006, 1, 2856-2860. [CrossRef] [PubMed]

58. Nakamura, H.; Kiyoshi, M.; Anraku, M.; Hashii, N.; Oda-Ueda, N.; Ueda, T.; Ohkuri, T. Glycosylation Decreases Aggregation and Immunogenicity of Adalimumab Fab Secreted from Pichia Pastoris. J. Biochem. 2020, 169, 435-443. [CrossRef] [PubMed]

59. Andre, S.; Pei, Z.; Siebert, H.; Ramstrom, O.; Gabius, H. Glycosyldisulfides from Dynamic Combinatorial Libraries as o-Glycoside Mimetics for Plant and Endogenous Lectins: Their Reactivities in Solid-Phase and Cell Assays and Conformational Analysis by Molecular Dynamics Simulations. Bioorganic Med. Chem. 2006, 14, 6314-6326. [CrossRef] [PubMed]

60. Findlow, J.; Taylor, S.; Aase, A.; Horton, R.; Heyderman, R.; Southern, J.; Andrews, N.; Barchha, R.; Harrison, E.; Lowe, A.; et al. Comparison and Correlation of Neisseria meningitidis serogroup $\mathrm{b}$ immunologic assay results and human antibody responses following three Doses of the Norwegian Meningococcal Outer Membrane Vesicle Vaccine MenBvac. Infect. Immun. 2006, 74, 4557-4565. [CrossRef]

61. Pizarro-Guajardo, M.; Ravanal, M.C.; Paez, M.D.; Callegari, E.; Paredes-Sabja, D. Identification of Clostridium Difficile Immunoreactive Spore Proteins of the Epidemic Strain r20291. Proteom. Clin. Appl. 2018, 12, 1700182. [CrossRef] [PubMed]

62. Wilharm, G.; Lehmann, V.; Krauss, K.; Lehnert, B.; Richter, S.; Ruckdeschel, K.; Heesemann, J.; Trülzsch, K. Yersinia Enterocolitica Type III Secretion Depends on the Proton Motive Force but Not on the flagellar motor Components MotA and MotB. Infect. Immun. 2004, 72, 4004-4009. [CrossRef] [PubMed]

63. Schwarz, F.; Fan, Y.-Y.; Schubert, M.; Aebi, M. Cytoplasmic n-Glycosyltransferase of Actinobacillus pleuropneumoniae Is an Inverting Enzyme and Recognizes the NX(S/T) Consensus Sequence. J. Biol. Chem. 2011, 286, 35267-35274. [CrossRef] [PubMed]

64. Choi, K.-J.; Grass, S.; Paek, S.; St. Geme, J.W.; Yeo, H.-J. The Actinobacillus Pleuropneumoniae HMW1C-Like Glycosyltransferase Mediates N-linked Glycosylation of the Haemophilus Influenzae Hmw1 Adhesin. PLoS ONE 2010, 5. [CrossRef] [PubMed]

65. Sing, A.; Roggenkamp, A.; Geiger, A.M.; Heesemann, J. Yersinia enterocolitica evasion of the Host Innate Immune Response by v Antigen-Induced Il-10 Production of Macrophages Is Abrogated in Il-10-Deficient Mice. J. Immunol. 2002, 168, 1315-1321. [CrossRef] [PubMed]

66. Cao, Z.Q.; Guo, X.L. The role of galectin-4 in physiology and diseases. Protein Cell 2016, 7, 314-324. [CrossRef] [PubMed]

67. Keeney, J.T.R.; Miriyala, S.; Noel, T.; Moscow, J.A.; St. Clair, D.K.; Butterfield, D.A. Superoxide Induces Protein Oxidation in Plasma and Tnf- $\alpha$ Elevation in Macrophage Culture: Insights into Mechanisms of Neurotoxicity Following Doxorubicin Chemotherapy. Cancer Lett. 2015, 367, 157-161. [CrossRef] [PubMed] 
68. Toscano, M.A.; Campagna, L.; Molinero, L.L.; Cerliani, J.P.; Croci, D.O.; Ilarregui, J.M.; Fuertes, M.B.; Nojek, I.M.; Fededa, J.P.; Zwirner, N.W.; et al. Nuclear Factor (NF)-KB controls expression of the immunoregulatory glycan-binding protein Galectin-1. Mol. Immunol. 2011, 48, 1940-1949. [CrossRef]

69. Zuñiga, E.; Rabinovich, G.A.; Iglesias, M.M.; Gruppi, A. Regulated expression of galectin-1 during B-cell activation and implications for T-cell apoptosis. J. Leukoc. Biol. 2001, 70, 73-79.

70. Ilaregui, J.M.; Croci, D.O.; Bianco, G.A.; Toscano, M.A.; Salatino, M.; Vermeulen, M.E.; Geffner, J.R.; Rabinovich, G.A. Tolerogenic Signals Delivered by Dendritic Cells to T Cells through a Galectin-1-driven immunoregulatory Circuit Involving Interleukin 27 and Interleukin 10. Nat. Immunol. 2009, 10, 981-991. [CrossRef] [PubMed]

71. Toscano, M.A.; Bianco, G.A.; Ilarregui, J.M.; Croci, D.O.; Correale, J.; Hernandez, J.D.; Zwirner, N.W.; Poirier, F.; Riley, E.M.; Baum, L.G.; et al. Differential Glycosylation OF Th1, Th2 and Th-17 Effector Cells selectively Regulates Susceptibility to Cell Death. Nat. Immunol. 2007, 8, 825-834. [CrossRef]

72. Toscano, M.A.; Commodaro, A.G.; Ilarregui, J.M.; Bianco, G.A.; Liberman, A.; Serra, H.M.; Hirabayashi, J.; Rizzo, L.V.; Rabinovich, G.A. Galectin-1 Suppresses Autoimmune retinal disease by promoting Concomitant th2- and T Regulatory-Mediated AntiInflammatory Responses. J. Immunol. 2006, 176, 6323-6332. [CrossRef] [PubMed]

73. Poncini, C.V.; Ilarregui, J.M.; Batalla, E.I.; Engels, S.; Cerliani, J.P.; Cucher, M.A.; van Kooyk, Y.; González-Cappa, S.M.; Rabinovich, G.A. Trypanosoma Cruzi infection Imparts a Regulatory Program in Dendritic Cells and T Cells via Galectin-1-Dependent Mechanisms. J. Immunol. 2015, 195, 3311-3324. [CrossRef] [PubMed]

74. Cedeno-Laurent, F.; Opperman, M.; Barthel, S.R.; Kuchroo, V.K.; Dimitroff, C.J. Galectin-1 Triggers an Immunoregulatory Signature in Th Cells Functionally Defined BY IL-10 Expression. J. Immunol. 2012, 188, 3127-3137. [CrossRef] [PubMed]

75. Dalotto-Moreno, T.; Croci, D.O.; Cerliani, J.P.; Martinez-Allo, V.C.; Dergan-Dylon, S.; Méndez-Huergo, S.P.; Stupirski, J.C.; Mazal, D.; Osinaga, E.; Toscano, M.A.; et al. Targeting Galectin-1 Overcomes Breast Cancer-Associated immunosuppression and prevents Metastatic Disease. Cancer Res. 2012, 73, 1107-1117. [CrossRef] [PubMed]

76. Starossom, S.C.; Mascanfroni, I.D.; Imitola, J.; Cao, L.; Raddassi, K.; Hernandez, S.F.; Bassil, R.; Croci, D.O.; Cerliani, J.P.; Delacour, D.; et al. Galectin-1 Deactivates Classically Activated Microglia and Protects from Inflammation-Induced Neurodegeneration. Immunity 2012, 37, 249-263. [CrossRef] [PubMed]

77. Keir, M.E.; Butte, M.J.; Freeman, G.J.; Sharpe, A.H. PD-1 and Its Ligands in Tolerance and Immunity. Annu. Rev. Immunol. 2008, 26, 677-704. [CrossRef] [PubMed]

78. Okumura, C.Y.; Baum, L.G.; Johnson, P.J. Galectin-1 on Cervical Epithelial Cells Is a Receptor for the Sexually Transmitted Human parasite Trichomonas vaginalis. Cell. Microbiol. 2008, 10, 2078-2090. [CrossRef]

79. Nita-Lazar, M.; Banerjee, A.; Feng, C.; Amin, M.N.; Frieman, M.B.; Chen, W.H.; Cross, A.S.; Wang, L.-X.; Vasta, G.R. Desialylation of Airway Epithelial Cells during Influenza Virus Infection Enhances Pneumococcal Adhesion via Galectin Binding. Mol. Immunol. 2015, 65, 1-16. [CrossRef]

80. Mahdavi, A.; Szychowski, J.; Ngo, J.T.; Sweredoski, M.J.; Graham, R.L.; Hess, S.; Schneewind, O.; Mazmanian, S.K.; Tirrell, D.A. Identification of Secreted Bacterial Proteins by Noncanonical Amino Acid Tagging. Proc. Natl. Acad. Sci. USA 2013, 111, 433-438. [CrossRef] [PubMed]

81. Heesemann, J.; Gross, U.; Schmidt, N.; Laufs, R. Immunochemical Analysis of Plasmid-Encoded Proteins Released by Enteropathogenic Yersinia Sp. Grown in Calcium-Deficient Media. Infect. Immun. 1986, 54, 561-567. [CrossRef] [PubMed]

82. Plowman, S.J.; Hancock, J.F. Ras Signaling from Plasma Membrane AND Endomembrane Microdomains. Biochim. Biophys. Acta (BBA)-Mol. Cell Res. 2005, 1746, 274-283. [CrossRef]

83. Belanis, L.; Plowman, S.J.; Rotblat, B.; Hancock, J.F.; Kloog, Y. Galectin-1 Is a Novel Structural Component and a Major Regulator of H-Ras Nanoclusters. Mol. Biol. Cell 2008, 19, 1404-1414. [CrossRef] [PubMed]

84. Wei, W.; Behloul, N.; Baha, S.; Liu, Z.; Aslam, M.S.; Meng, J. Dimerization: A Structural Feature for the Protection of Hepatitis e Virus Capsid Protein against Trypsinization. Sci. Rep. 2018, 8. [CrossRef]

85. Tumitan, A.R.; Monnazzi, L.G.; Ghiraldi, F.R.; Cilli, E.M.; de Medeiros, B.M. Pattern of Macrophage Activation Inyersinia-Resistant Andyersinia-Susceptible Strains of Mice. Microbiol. Immunol. 2007, 51, 1021-1028. [CrossRef] [PubMed]

86. Liew, F.Y.; Li, Y.; Moss, D.; Parkinson, C.; Rogers, M.V.; Moncada, S. Resistance Toleishmania Major Infection Correlates with the Induction of Nitric Oxide Synthase in Murine Macrophages. Eur. J. Immunol. 1991, 21, 3009-3014. [CrossRef] [PubMed]

87. Monnazzi, L.G.; Carlos, I.Z.; deMedeiros, B.M. Influence of Yersinia pseudotuberculosis Outer Proteins (YOPS) on Interleukin-12, Tumor Necrosis Factor Alpha and Nitric Oxide Production BY Peritoneal Macrophages. Immunol. Lett. 2004, 94, 91-98. [CrossRef]

88. Tansini, A.; de Medeiros, B.M. Susceptibility to Yersinia Pseudotuberculosis infection Is Linked to the Pattern of Macrophage Activation. Scand. J. Immunol. 2009, 69, 310-318. [CrossRef]

89. Virág, L.; Jaén, R.I.; Regdon, Z.; Boscá, L.; Prieto, P. Self-Defense of Macrophages against Oxidative Injury: Fighting for Their Own Survival. Redox Biol. 2019, 26, 101261. [CrossRef]

90. Kim, P.K.M.; Zamora, R.; Petrosko, P.; Billiar, T.R. The Regulatory Role of Nitric Oxide in Apoptosis. Int. Immunopharmacol. 2001, 1, 1421-1441. [CrossRef]

91. Giordano, D.; Li, C.; Suthar, M.S.; Draves, K.E.; Ma, D.Y.; Gale, M., Jr.; Clark, E.A. Nitric oxide controls an inflammatory-like Ly6C(hi)PDCA1+DC subset that regulates Th1 immune responses. J. Leukoc. Biol. 2011, 89, 443-455. [CrossRef]

92. Xue, Q.; Yan, Y.; Zhang, R.; Xiong, H. Regulation of iNOS on Immune Cells and Its Role in Diseases. Int. J. Mol. Sci. 2018, 19, 3805. [CrossRef] 
93. Hu, G.; Su, Y.; Kang, B.H.; Fan, Z.; Dong, T.; Brown, D.R.; Cheah, J.; Wittrup, K.D.; Chen, J. High-throughput phenotypic screen and transcriptional analysis identify new compounds and targets for macrophage reprogramming. Nat. Commun. 2021, 12, 773. [CrossRef] [PubMed]

94. Zheng, Y.; Lilo, S.; Brodsky, I.E.; Zhang, Y.; Medzhitov, R.; Marcu, K.B.; Bliska, J.B. A Yersinia effector with Enhanced Inhibitory Activity on the Nf-Kb PATHWAY Activates the nlrp3/Asc/Caspase-1 Inflammasome in Macrophages. PLoS Pathog. 2011, 7. [CrossRef] [PubMed]

95. Fuertes, M.B.; Molinero, L.L.; Toscano, M.A.; Ilarregui, J.M.; Rubinstein, N.; Fainboim, L.; Zwirner, N.W.; Rabinovich, G.A. Regulated Expression of Galectin-1 during T-Cell Activation Involves lck and Fyn Kinases and Signaling through mek1/Erk, P38 MAP Kinase And p70S6kinase. Mol. Cell. Biochem. 2004, 267, 177-185. [CrossRef] [PubMed] 